Scholarship Repository

University of Minnesota Law School

Articles

Faculty Scholarship

2007

\title{
Secrecy and Separated Powers: Executive Privilege Revisited
}

Heidi Kitrosser

University of Minnesota Law School, hdk@umn.edu

Follow this and additional works at: https://scholarship.law.umn.edu/faculty_articles

Part of the Law Commons

\section{Recommended Citation}

Heidi Kitrosser, Secrecy and Separated Powers: Executive Privilege Revisited, 92 IowA L. Rev. 489 (2007), available at https://scholarship.law.umn.edu/faculty_articles/53.

This Article is brought to you for free and open access by the University of Minnesota Law School. It has been accepted for inclusion in the Faculty Scholarship collection by an authorized administrator of the Scholarship Repository. For more information, please contact lenzx009@umn.edu. 


\title{
Secrecy and Separated Powers: Executive Privilege Revisited
}

\author{
Heidi Kitrosser
}

INTRODUCTION

I. INTRODUCTION TO EXECUTIVE PRIVILEGE: FURTHER BACKGROUND AND RELATIONSHIP TO CONGRESSIONAL. INFORMATION DEMANDS

II. EXISTING DOCTRINE AND SCHOLARSHIP ......................................500

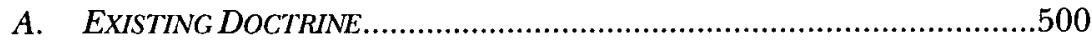

B. MAJOR SCHOLARLY ARGUMENTS..........................................505

III. SECRECY AND SEPARATEd POWERS: THE ARgument FOR A NeW

APProach to EXECUTIVE Privilege.

A. GETTING TO THE NEW APPROACH: OVERLAPPING POWERS AND THE

SPECIAL CONSTITUTIONAL SIGNIFICANCE OF INFORMATION

CONTROL

1. History and Executive Privilege

2. Article I, Article II, Functional Balancing, and Judicial Restraint

3. The Role of Information Control's Constitutional Significance

4. Elaboration on the Shallow/Deep Secrecy Distinction and Its Constitutional Relevance

* Associate Professor, University of Minnesota Law School. I am very grateful for insightful comments on early ideas and drafts from: Ricardo Bascuas, Mike Cahill, Guy Charles, Jim Chen, Jenny Diamond Cheng, David Dana, Steven Dean, Mark Fenster, David Fischer, Dan Gifford, Joel Goldstein, Jill Hasday, Kristen Hickman, Claire Kelly, Lyrissa Lidsky, Jason Mazzone, Brett McDonnell, Mike Paulsen, Jeff Rachlinsky, Dana Brakman Reiser, David Reiss, Neil Richards, Daria Roithmayr, Adam Samaha, Michael Simons, Larry Solum, David Stras, Kevin Washburn, and Peter Weidenbeck. Very helpful comments also were provided in workshops at the University of Minnesota and at the Jurisgenesis Conference hosted by Washington University in St. Louis. Many thanks also to Steven Aftergood for an enlightening telephone conversation on government secrecy. Summer research support was provided by Brooklyn Law School and the University of Minnesota Law School. 
B. THE CONSTITUTIONAL FOUNDATIONS OF THE ARGUMENT FOR

SHALLOW AND POLITICALLY CHECKABLE SECRECY

1. Openness as the Presumptive Constitutional Norm in

Inter-Branch and Government-Populace Relations

a. Popular Sovereignty

b. The First Amendment.

c. The Public, Dialogic Nature of the Legislative, Treaty-

Approval, and Nomination Processes.

2. The Need for Occasional Secrecy

3. Reconciling the Two Elements: Keeping Secrecy Shallow and Politically Checkable

a. The Logical Place of Shallow and Politically Checkable Secrecy in Constitutional Structure

b. Article I, Section 5 522

c. The Unitary Presidency .524

d. Constitutional Convention Secrecy. 526

IV. IMPLEMENTING THE SOlution: The Constitutionally

CONCLUSIVE NATURE OF STATUTORY OPENNESS REQUIREMENTS

A. LEGISLATIVE ACCESS DECISIONS AS THE PRACTICAL

MANIFESTATION OF THE SHALLOW/POLJTICALLY CHECKABLE

SECRECY SOLUTION

B. THE PROTECTIVE NATURE OF STATUTES'RELATTVE BREADTH AND OF THE LEGISLATIVE PROCESS

C. LIMITATIONS ON THE ARGUMENT

1. The Scope of Congress's Legislative and Oversight Domain

2. Individual Rights Based Objections

3. Statutory Interpretation.

V. Reflections on The Policy Nature of THE QUeSTIONS AT ISSUE in Executive Privilege Clashes AND Judicial TENDENCIES IN EVALUATING THOSE QUESTIONS

VI. CONCLUSION 
I was struck dumb with astonishment at the sentiments . . . [t]hat the executive alone shall have the right of judging what shall be kept secret, and what shall be made public, and that the representatives of a free people, are incompetent to determine on the interests of those who delegated them.

- Benjamin Franklin'

Bureaucracy naturally welcomes a poorly informed and hence a powerless parliament-at least in so far as ignorance somehow agrees with the bureaucracy's interests.

- Max Weber ${ }^{2}$

\section{INTRODUCTION}

The Bush administration has inspired renewed interest in the topic of executive branch secrecy, with many claiming that this is "the most secretive administration in our history." administration is unprecedented, the very tendency toward executive secrecy is nothing new. As Arthur Schlesinger, Jr. has written, a "religion of secrecy" has been ascendant in the American Presidency since roughly World War II, serving as an "all-purpose means by which the American Presidency [may] dissemble its purposes, bury its mistakes, manipulate its citizens, and maximize its power."

Executive secrecy manifests itself in a staggeringly large (and growing) system of information classification ${ }^{5}$ and in case-by-case refusals to disclose information sought by others. While case-by-case refusals often occur informally, they are most visible and most notorious when they take the form of executive privilege claims. A claim of executive privilege is generally a

1. Daniel N. Hoffman, Governmental Secrecy and the Founding FatHers 101 (1981) (alterations in original) (quoting Philadelphia General Advertiser, Dec. 30, 1793, at 3; see also Editorial of Dec. 28, 1793, id. at 3; Letter of "Z," Dec. 31, 1793, id. at 3).

2. DANIEl PATRICK MOVNIHAN, SECRECY 143 (1998) (quoting Max Weber, Bureaucracy, in EsSAYS IN SOCIOLOGY 196, 234 (H.H. Gerth \& C. Wright Mills trans. \& eds., Oxford University Press 1946)).

3. Ted Widmer, Making War, N.Y. TIMEs BOOK REV., May 9, 2004, at 7 (reviewing BoB WOODWARD, PlaN OF ATTACK (2004)); see also, e.g., JOHN W. DEAN, WORSE THAN WATERGATE: THE SECRET PRESIDENCY OF GEORGE W. BuSH xi (2004); William G. Weaver \& Robert M. Pallitto, State Secrets and Executive Power, 120 POL. SCI. Q. 85, 108 (2005); Dorothy Samuels, Editorial, Psst. President Bush Is Hard at Work Expanding Government Secrecy, N.Y. TIMES, Nov. 1, 2004, at A24.

4. ARTHuR M. SCHLESINGer, JR., THE IMPERIAL PRESIDENCY 345 (1973).

5. See, e.g., Editorial, Credible Classifications, WASH. POST, July 13, 2005, at A14; Christina E. Wells, "National Security" Information and the Freedom of Information Act, 56 ADMIN. L. REV. 1195, 1201-02 (2004); Scott Shane, Since 2001 (Sharp) Increase in the Number of Documents Classified by the Government, N.Y. TIMES, July 3, 2005, § 1; Emerging Threats, and Int'l Relations of the H. Comm. on Gov't. Reform: Hearing Before the Subcomm. on National Security, 108th Cong. (2005) (formal statement of J. William Leonard, Dir., Info. Sec. Oversight Office of Nat'l Archives and Records Admin.), http://www.fas.org/sgp/congress/2005/030205leonard.html. 
claim by the President of a constitutional right to withhold information from Congress, the courts, or persons or agencies empowered by Congress to seek information. ${ }^{6}$ Executive privilege is not mentioned in the text of the Constitution, ${ }^{7}$ nor is it statutorily authorized, although some commentators call for statutory recognition of the doctrine. ${ }^{8}$ Rather, executive privilege claims are based on the notion that some information requests effectively infringe on the President's Article II powers, threatening his ability to receive candid advice or to protect national security. ${ }^{9}$ Recent controversies involving executive privilege include Vice President Cheney's refusal to turn over documents relating to energy policy development that were sought by public interest groups under a public disclosure statute ${ }^{10}$ and a number of tussles between the White House and investigators, both congressional and commission-based, regarding September 11 and Iraq-related information requests. ${ }^{11}$

This Article assesses the constitutional validity of executive privilege, focusing solely on executive privilege disputes between Congress and the President or other high-ranking executive branch officers. This Article defines such conflicts broadly to include clashes over information sought directly by Congress (or by a committee or subcommittee thereof), clashes over information sought by individuals through congressionally drawn public access statutes, and clashes over information sought by congressionally created agencies.

The time is ripe to revisit the constitutional validity of executive privilege. Reassessing executive privilege has significance both for the doctrine itself and for executive branch secrecy more generally-including the nearly complete discretion accorded the executive branch to classify information $^{12}$-as the justifications for the two overlap substantially. ${ }^{13}$

6. See, e.g., Mark J. Rozell, Executive Privilege Revived? Secrecy and Conflict During the Bush Presidency, 52 DUkE L.J. 403, 404 (2002). The term "presidential communications privilege" sometimes is used to distinguish the privilege discussed in this Article from other forms of immunity labeled "executive privilege," such as immunity from civil suit while in office. See, e.g., In re Sealed Case, 121 F.3d 729, 735 n.2 (D.C. Cir. 1997). This Article will, however, use the term "executive privilege" to refer solely to the communications aspect of the privilege.

7. See Rozell, supra note 6, at 403-04.

8. See, e.g., Saikrishna Bangalore Prakash, A Critical Comment on the Constitutionality of Executive Privilege, 83 MINN. L. REV. 1143, 1148, 1186-89 (1999).

9. See, e.g., U.S. v. Nixon, 418 U.S. 683, 706 (1974); MARK J. Rozell, EXECUTIVE Privilege: Presidential Power, Secrecy, And ACCOUntability 43-48 (2002); Archibald Cox, Executive Privilege, 122 U. PA. L. REv. 1383, 1386, 1410 (1974); Randall K. Miller, Congressional Inquests: Suffocating the Constitutional Prerogative of Executive Privilege, 81 MINN. L. REV. 631, 640-49 (1997); Rozell, supra note 6, at 404.

10. See infra Part I.

11. See infra Part I.

12. See, e.g., Wells, supra note 5, at 1199; Note, Keeping Secrets: Congress, the Courts and National Security Information, 103 HARV. L. REV. 906, 907-10 (1990) [herinafter Note, Keeping Secrets]. 
Furthermore, the impact of White House secrecy on current events highlights the systemic significance of information control both between the political branches and between those branches and the people.

This Article concludes that there is no such thing as a constitutionally based executive privilege, and courts-in the face of executive privilege claims-should order compliance with any statutorily authorized demands for executive branch information. This conclusion is reached in two steps. First, perusal of Article I's list of legislative powers and Article II's list of presidential powers does not clearly resolve the question of executive privilege's constitutional legitimacy. To the contrary, such perusal alone offers fair ground to deem control of executive branch information both within Congress's "sweeping clause" power and within the President's power to execute the law and to perform other Article II tasks. Absent further analysis, then, one might be tempted to conclude that the judiciary and some scholars have matters well in hand insofar as they champion a balancing test that weighs congressional interests in openness against presidential interests in secrecy. Alternatively, one might side with those who deem the matter a political question, unfit for resolution by the courts.

Yet analysis of the matter ought not to end there. To the contrary, this Article argues that there is an additional analytical step, one unrecognized to date in the doctrine and scholarship that categorically resolves executive privilege clashes in favor of statutorily authorized access demands. This second step involves gleaning from a broader analysis of the Constitution the insight that information has special constitutional significance, and that it thus is unlike any other tool of power. Specifically, such analysis suggests that secrecy in government sometimes is a necessary evil, but secrecy within the political branches must, to be legitimate, remain a politically controllable tool of the people. To keep government secrecy within the ultimate control of the people, and hence non-tyrannical, secrecy must be subject to policies formulated through processes that themselves are visible and dialogic. Policies so formulated are conclusive over executive privilege claims for two closely related reasons. First, the process of creating such policies entails the type of public, dialogic protections that the Constitution generally demands for regulatory measures. Second, given the unique dangers of secrecy to a democratic system as reflected throughout the Constitution, any openness directives generated through such careful and protective processes must be realistically enforceable.

A useful conceptual hook for understanding these points is a concept developed largely in the political science literature: that of shallow and deep secrecy. Shallow secrecy is secrecy, the very existence of which is known, even while the secrets' contents remain unknown. Deep secrecy is secrecy,

13. See Note, Keeping Secrets, supra note 12, at 917. 
the fact of which itself is a secret. ${ }^{14} \mathrm{~A}$ rough way to state the points made in the preceding paragraph is that the Constitution demands that secrets generated by the political branches be shallow and, to make the shallowness meaningful, politically checkable. Such shallowness and political checkability should manifest itself in two respects. First, political branch secrets should be subordinate to any access requirements themselves formulated through an open, dialogic process. Hence, secrets should be shallow and politically checkable in the broad sense that they are subordinate to policies that themselves are transparent and politically alterable. Second, specific secrets should be subject to being made shallow or even to having their contents revealed both as a means to enforce the governing policies and as a means to effectuate the Constitution's textual, structural, and historical wariness of government secrecy.

This Article thus uses as shorthand the phrase "shallow and politically checkable" to describe the condition that the Constitution demands of political branch secrecy. The natural mechanisms to keep secrecy shallow and politically checkable are statutory authorizations to Congress, to the public, and to agencies to demand information. The relatively public, dialogic and deliberative process of legislating helps to ensure that macroquestions about secrecy and openness are aired in the sunlight, even if the resulting policies allow some secrecy. Furthermore, statutory openness mandates create a second level of activity on which specific instances of secrecy can be challenged and checked by Congress and the people. This second level of activity has particular significance for the deep/shallow secrecy distinction. As secrets often exist in layers, stripping away one layer of secrecy may well expose the existence of others. Perhaps the most famous example of this point is the revelation of Richard Nixon's oval office tapes. It was only through its ability to question former presidential aide Alexander Butterfield that the Senate Select Committee on Presidential Campaign Activities discovered the tapes' existence in the first place. ${ }^{15}$ Once the tapes became a shallow rather than a deep secret, further legal and political maneuvering could take place in an effort to discover the tapes' content. ${ }^{16}$

14. AMy GUTMANn \& DeNNIS ThOMPSON, DEMOCRACY AND DisAGREEMENT 121-26 (1996); KIM LANE SCHEPPELE, LEGAL SECRETS: EQUALITY AND EFFICIENCY IN THE COMMON LAW 21-22 (1988); cf. SISELA BOK, SECRETS 112, 202-03 (1982); see also Heidi Kitrosser, Secrecy in the Immigration Courts and Beyond: Considering the Right to Know in the Administrative State, 39 HARV. C.R.-C.L. L. REV. 95, 100 (2004); Adam M. Samaha, Government Secrets, Constitutional Law, and Platforms for Judicial Intervention, 53 UCLA L. REV. 909, 920 n.41 (2006); Dennis F. Thompson, Democratic Secrecy, 114 POL. SCI. Q. 181, 183 (1999).

15. See Senate Select Comm. on Presidential Campaign Activities v. Nixon, 498 F.2d 725, 726-27 (D.C. Cir. 1974).

16. See id. at 726-29. While Senate Select Committee involved congressional efforts to obtain the tapes, prosecutorial efforts also were made to discover some of the tapes in the context of criminal proceedings related to the Watergate controversy. The latter efforts manifested 
The nature of the legislative process relative to that of the presidential office suggests two additional reasons to deem legislative judgments as to secrecy or openness conclusive over executive privilege objections. First, from a perspective that understands constitutional structure to value openness and to see secrecy as a necessary evil that must remain shallow and politically controllable, the President's special capacity for secrecy suggests not an Article II right to operate in secret, but rather the crucial importance of effective political controls over that capacity. This point helps to situate the executive privilege issue within the larger context of statutory control over presidential powers. As others have observed, Articles I and II leave little for the President to do absent statutory authorization. This framework reflects an understanding of the relative strengths and dangers posed by a large, deliberative body and by a unitary, energetic, and potentially secretive actor. While this framework does not mean that Congress can never unconstitutionally infringe on Article II by constraining presidential powers once granted and defined, it does suggest that information control, given its special constitutional significance, must remain within the relatively safe, open, and deliberative realm of the legislature so as to allow for robust political checks against presidential secrecy. Second, the legislative process, with its built-in inefficiencies and built-in role for the President through the veto power, provides ample safeguards against any potential Article II harms caused by forced disclosure.

Part I of this Article begins by providing further background on and examples of executive privilege claims raised in the face of legislatively based access demands. Part II analyzes existing doctrine and scholarship, explaining that it provides a useful starting point for analysis, but that more work must be done because existing accounts fail to consider the special constitutional role of information. Part III elaborates on this role. Part III.A explains that a judicial balancing test might be an appropriate response to executive privilege claims were a tool of power other than information at stake, but that such an approach ignores information's special constitutional significance. Part III.A summarizes this significance and elaborates on the meaning and constitutional relevance of the phrase "shallow and politically checkable secrecy." Part III.B explains that the Constitution reflects a faith in openness as the operative norm between the political branches and between those branches and the people and that the Constitution also leaves room for occasional government secrecy. It also explains that the Constitution reflects a compromise between openness and secrecy by suggesting support only for political secrecy that is shallow and politically checkable. Part IV explains that constitutional support for shallow and politically checkable secrecy naturally manifests itself in allowing 
presidential secrecy to be overseen through statutorily authorized access demands. Part IV also explains that this Article's approach leaves some room for objections to access demands based on rationales other than executive privilege. Part $\mathrm{V}$ reflects on the policy nature of the assertions underlying executive privilege claims as well as the experience with judicial assessment of those assertions. With respect to the former, Part $\mathrm{V}$ cites current and historical accounts of the often disastrous consequences of presidential secrecy. While these accounts do not mean that presidential secrecy is never appropriate, they shed light on the fact that pro-secrecy arguments are contestable policy judgments, not static constitutional truths. By juxtaposing this point with a reminder of the judiciary's tendency to defer to executive privilege claims, Part $\mathrm{V}$ sheds light on the wisdom of an approach to government secrecy grounded in checking mechanisms borne of political competition.

\section{INTRODUCTION TO EXECUTIVE PRIVILEgE: FURTHER BACKGROUND AND RELATIONSHIP TO CONGRESSIONAL INFORMATION DEMANDS}

Although the term "executive privilege" was not used until the Eisenhower administration, ${ }^{17}$ conflicts between the President and coordinate branches regarding information access date back to the earliest years of the American republic. ${ }^{18}$ Beginning with the Eisenhower administration, some Presidents have articulated explicit policies on executive privilege through letters, public statements, and memoranda. ${ }^{19}$ Among the conditions typically articulated in executive privilege policies are pledges that the privilege will be used only if invoked or approved by the President ${ }^{20}$ and that it will not be used to cover up executive branch wrongdoing. ${ }^{21}$ Not surprisingly, wide chasms can exist between policy and practice. For example, Richard Nixon expressed the view that "the scope of executive privilege must be very narrowly construed" and pledged "to invoke this authority only in the most compelling circumstances and after a rigorous inquiry into the actual need for its exercises."22 These statements are belied, of course, by Nixon's attempts to use the privilege to cover up criminal activity during the Watergate scandal. ${ }^{23}$ Similar points have been made with respect to uses of the privilege and the withholding of executive information generally by the

17. RozELL, supra note 9 , at 39 .

18. See, e.g., id., at 28-43; RAOUl Berger, EXeCUtive Privilege: A Constitutional Myth 163-208 (1974); Prakash, supra note 8, at 1177-85; see also infra Part III.A.1.

19. RozELL, supra note 9 , at 39-43, 54-57, 73-76, 84-87, 94-95, 106-08, 123-24.

20. See id. at $41-42,56-57,95,124$.

21. Id. at $56-57,124$.

22. Id. at 55-56.

23. See, e.g., U.S. v. Nixon, 418 U.S. 683 (1974); Nixon v. Sirica, 487 F.2d 700 (D.C. Cir. 1973). 
Reagan administration during the Oliver North trial ${ }^{24}$ and by the Clinton administration during inquiries such as the Whitewater and "Travelgate" controversies. ${ }^{25}$ Of course, it is difficult, if not impossible, to identify discrepancies between executive privilege policy and practice where a President succeeds in an executive privilege claim and thus blocks discovery of the very information that might have shed light on such discrepancy. ${ }^{26}$

As noted above, this Article focuses solely on executive privilege disputes between Congress and the President, or other high-ranking executive officials. The disputes with which this Article is concerned thus can arise in one of several ways. First, Congress may exercise its legislative power to create a public information access statute and the President or another high-ranking executive officer may resist disclosure under such statute on explicit or implicit executive privilege grounds. A recent example of such a clash is Vice President Cheney's refusal to release information sought by public interest groups under public disclosure provisions of the Federal Advisory Committee Act ("FACA"). ${ }^{27}$ In the FACA, Congress provided that federal advisory committees must follow a number of public disclosure requirements including holding public meetings and making transcripts, records, and other materials available to the public upon request. ${ }^{28}$ Shortly after taking office in 2001, President Bush created the National Energy Policy Development Group ("NEPDG") and placed Vice President Cheney at its head. ${ }^{29}$ Two public interest groups sought information about NEPDG and its membership, arguing that NEPDG met the statutory definition of a federal advisory committee and that the committee had shirked its public disclosure obligations under the FACA. ${ }^{30}$ While Vice President Cheney technically did not invoke executive privilege in response, his argument was steeped in executive privilege principles. Specifically, he maintained that the separation of powers prevents the FACA from applying to the Vice President because such application would impede the Vice President's ability to receive candid advice. ${ }^{31}$

24. See, e.g., harold honguU KoH, The national Security Constitution: Sharing POWER AFTER THE IRAN-CONTRA AFFAIR 29-34 (1987).

25. RozELL, supra note 9 , at 124-46.

26. See, e.g., id., at 146; cf. КоH, supra note 24, at 31-32.

27. 5 U.S.C. app. $\$ \$ 1-15$ (b).

28. Id. $\$ \S 10,11$. The FACA also imposes other requirements on federal advisory committees beyond the public disclosure mandate. See id. $\$ \$ 9,10$.

29. Walker v. Cheney, 230 F. Supp. 2d 51, 54 (D.D.C. 2002); Judicial Watch v. Nat'l Energy Policy Dev. Group, 219 F. Supp. 2d 20, 24 (D.D.C. 2002); NAT. ENERcy POLICY DEv. Group, REPORT viii (2001) [hereinafter NEPDG Report]; Vikram David Amar, The Cheney Decision-A Missed Chance to Straighten Out Some Muddled Issues, CATO Sup. CT. REv. 185, 185 (2003-2004).

30. Cheney v. U.S. Dist. Court, 542 U.S. 367, 372 (2004); Judicial Watch, 219 F. Supp. 2d at 23-24, 33.

31. Cheney, 542 U.S. at 375; In re Cheney, 334 F.3d 1096, 1100 (D.C. Cir. 2003); Judicial Watch, 219 F. Supp. 2d at 44-45; Amar, supra note 29, at 187-89; see John W. Dean, More 
Second, Congress may exercise its legislative power to create a commission with information-gathering authority that explicitly or implicitly applies to the President or other high-ranking executive officers, and such officers may resist disclosure on explicit or implicit grounds of executive privilege. A recent example of this is the National Commission on Terrorist Attacks upon the United States ("Commission"), created by statute in November of $2002 .{ }^{32}$ Congress charged the Commission with the tasks of "examin[ing] and report[ing] upon the facts and causes relating to the terrorist attacks of September 11, 2001" and "recommend[ing] . . corrective measures that can be taken to prevent [future] acts of terrorism." ${ }^{33}$ The Commission had the statutory power to hold hearings and to seek out witnesses and information. ${ }^{34}$ The Commission was authorized to issue subpoenas with the consent either of the Commission Chairman and Vice-Chairman or of six members of the Commission. ${ }^{35}$ Subpoenas were enforceable in federal district court through civil contempt actions. ${ }^{36}$ Subpoenas also could be enforced, upon the vote of a majority of Commissioners, through criminal contempt actions. ${ }^{37}$ The Commission encountered resistance from the White House with respect to some important information sought, including the public testimony of then National Security Advisor Condoleeza Rice, the testimony of President George W. Bush, and the turning over of presidential daily briefings. ${ }^{38}$ In justifying its resistance, the White House cited national security concerns as well as the need for candor in White House discussions and the consequent danger of allowing high-level officials to testify about such discussions. ${ }^{39}$ The Commission was reluctant to use its subpoena power, and the White House

Litigation Will Follow on the Cheney Energy Task Force, CNN.COM, July 5, 2004, http://www.cnn.com/2004/LAW/07/05/dean.cheney/index.html.

32. National Commission on Terrorist Attacks upon the United States, Pub. L. No. 107306,116 Stat. 2384 (codified at 6 U.S.C. $\$ 101$ (Supp. II 2002)).

33. $\$ 602(1),(5), 116$ Stat. 2408.

34. $\$ 605(a)(1), 116$ Stat. 2410.

35. $\S 605(\mathrm{a})(2), 116$ Stat. 2410.

36. $\$ 605(\mathrm{a})(2)(\mathrm{B})(\mathrm{i}), 116$ Stat. $2410-11$.

37. $\$ 605$ (a) (2) (B) (ii), 116 Stat. 2411.

38. See, e.g., Edward Epstein, Bush Relents-Rice to Testify to 9/11 Panel, President Says He Wants to Give the Public a "Complete Picture," S.F. Chron., Mar. 31, 2004, at A1; James G. Lakely, WASH. TIMES, Mar. 31, 2004, at A1; How the Bush Administration Sought to Obstruct and Discredit the 9/11 Investigation, AM. PROGRess, July 20, 2004, http://www.americanprogress.org/ site/pp.asp?c=bi]RJ8OVF\&b=124722; Sharon Kehnemui, Senators Push for Rice Testimony, FOXNEwS.COM, Mar. 30, 2004, http://www.foxnews.com/printer_friendly_story/ 0,3566,115569,00.html; Chris Strohm, 911 Commission Sets Precedent for Executive Privilege Challenges, GovexEC.COM, July 29, 2004, http://www.govexec.com/dailyfed/0704/ $072904 \mathrm{cl} . \mathrm{htm}$.

39. See supra note 38 . 
and the Commission eventually reached agreements without resorting to such power. ${ }^{40}$

Third, Congress may itself seek information for investigative purposes, usually through a committee or subcommittee of one of its chambers, and the President or other high-ranking executive officers may resist testifying or turning over information on explicit or implicit grounds of executive privilege. A recent example involves the Joint Inquiry of the Select Committee of the Senate and the Permanent Select Committee of the House of Representatives Regarding the Terrorist Attacks of September 11, 2001 ("Joint Inquiry"). ${ }^{41}$ The Joint Inquiry was formed by the two committees named in its title to help study terrorist threats against the United States, including the circumstances surrounding the attacks of September 11, to assess weaknesses in the United States' ability to address such threats and to make recommendations. ${ }^{42}$ The Joint Inquiry preceded the 9/11 Commission. Indeed, Congress formed the Commission partly to follow up on the work of the Joint Inquiry ${ }^{43}$ in light of perceptions that the latter had failed to make much headway. ${ }^{44}$ These perceptions were due in part to the Joint Inquiry's failure to obtain some important information. ${ }^{45}$ The information failures were due largely to executive privilege and related clashes, including White House refusals to turn over presidential daily briefings. ${ }^{46}$ Although the Joint Inquiry did not use its subpoena authority, congressional committees have a statutory subpoena power and the statutory

40. Id. See also, e.g., Brian Montopoli, Schlep to Judgment, WASH. MONTHLY, Sept. 2003, available at http://www.washingtonmonthly.com/features/2003/0309.montopoli.html; Letter from Alberto Gonzales, White House Counsel, to Thomas Kean, 9-11 Commission Chairman, and Lee Hamilton, 9-11 Commission Vice Chairman, (Mar. 30, 2004), available at www.foxnews.com/printer_friendly_story/0,3566,115618,00.html; Statement of September $11^{\text {th }}$ Commission in Response to White House Counsel Letter (Mar. 30, 2004), available at www.foxnews.com/printer_friendly_story/0,3566,115620,00.html.

41. See 148 CONG. REC. H3493 (daily ed. June 12, 2002) (statement of Rep. Goss).

42. Id.

43. National Commission on Terrorist Attacks upon the United States, Pub. L. No. 107306,116 Stat. 2384 (codified at 6 U.S.C. $\$ 602$ (3) (A) (Supp. II 2002)).

44. See, e.g., Eric Boehlert, Is the 9/11 Commission Too Soft?, VoICES OF SEPT. $11^{\text {th }}$, Oct. 10 , 2003, http://www.voicesofsept11.org/news/101003.php; Montopoli, supra note 40.

45. See, e.g., Michael Isikoff \& Mark Hosenball, The Secrets of September 11, NewsweEk, Apr. 30, 2003, available at http://www.keepmedia.com/jsp/article_detail_print.jsp (same); see also Eric Boehlert, supra note 44; John W. Dean, The 9/11 Report Raises More Serious Questions About the White House Statements on Intelligence, FINDLAW.COM, July 29, 2003, http://writ.findlaw.com/ dean/20030729.html; Montopoli, supra note 40; cf., e.g., U.S. DEPARTMENT OF STATE, INTERNATIONAL INFORMATION PROGRAMS, SENATORS SPAR OVER JOINT COMMITTEE'S SEPTEMBER 11 REPORT, WASHINGTON FILE, JULY 25, 2003, available at http://www.iwar.org.uk/newsarchive/2003/07-25-2.htm (discussing secrecy in the delayed release and extensive classification of the Joint Inquiry Report).

46. Dean, supra note 45; Montopoli, supra note 40. 
ability to enforce such power through criminal contempt actions upon the majority vote of a congressional chamber. ${ }^{47}$

\section{EXISTING DOCTRINE AND SCHOLARSHIP}

Existing doctrine and scholarship that support a qualified executive privilege provide useful insights with respect to the possible costs of openness. Furthermore, existing scholarship opposed to executive privilege illuminates the questionable nature of any claims grounded in the notion of broad executive discretion to operate apart from congressional oversight and direction. These arguments suffer, however, from their failure to look beyond the list of powers in Articles I and II to consider whether the Constitution sheds special light on information control as a political tool of power. With respect to existing doctrine and scholarship supportive of a qualified executive privilege, this omission leads analytically and as a practical matter to excessive deference to the executive branch. With respect to scholarly arguments against executive privilege, this omission forces reliance on a rejection of implied presidential powers generally. The latter proposition is somewhat questionable. In any event, the alternative argument that information control cannot be deemed an implied presidential power for reasons specific to that power substantially enhances the position against executive privilege.

\section{A. EXISTING DOCTRINE}

Executive privilege clashes between Congress and the White House rarely reach the courthouse and are even less likely to result in judicial merits decisions. ${ }^{48}$ Nonetheless, existing doctrine on executive privilege plays an important shadow function even in those executive privilege disputes that never approach judicial intervention. For one thing, judicial doctrine infuses the public debate on executive privilege, with executive branch officials frequently echoing the Supreme Court's pronouncement in United States $v$. Nixon to the effect that presidents must be able to discuss matters with advisors in secret to ensure candor. ${ }^{49}$ When the White House

47. 2 U.S.C. $\$ \$ 192,194$ (2000); Todd D. Peterson, Prosecuting Executive Branch Officials for Contempt of Congress, 66 N.Y.U. L. REV. 563,568 (1991). There is also some statutory question as to whether Congress currently possesses a civil contempt remedy with respect to executive branch officers. Compare Neil Devins, Congressional-Executive Information Access Disputes: A Modest Proposal-Do Nothing, 48 ADMIN. L. REv. 109, 117 (1996), with Peterson, supra, at 567-68. Furthermore, Congress has inherent authority itself to fine and even temporarily imprison recalcitrant witnesses, although this power has not been used in many years. See Devins, supra, at 116; Peterson, supra, at 567.

48. See Joel D. Bush, Congressional-Executive Access Disputes: Legal Standards and Political Settlements, 9 J.L. \& POL. 719, 735 (1993).

49. See United States v. Nixon, 418 U.S. 683, 705-06 (1974). For recent executive branch invocations of this rationale, see, e.g., Epstein, supra note 38; Shannen W. Coffin, Energy and the Executive: Bush and Cheney Have Rightly Stood Firm in the Ongoing Energy Controversy, NAT'L REV. 
resisted having Condoleeza Rice testify publicly and under oath before the 9/11 Commission, for example, Rice emphasized on national television that "[n]othing would be better, from my point of view, than to be able to testify," but the legal principles at issue simply prevented it. ${ }^{50}$ Furthermore, the possibility of judicial intervention surely impacts the willingness of both Congress (or its agents or the public acting pursuant to statutory right) and the Executive to press their respective positions. Members of the 9/11 Commission stated, for example, that they were reluctant to seek judicial resolution of information disputes because of the substantial, possibly prohibitive, delay that a court battle would engender. ${ }^{51}$ Similarly, the chairman of the House Government Reform Committee noted his reluctance to subpoena the Bush administration for documents related to Hurricane Katrina, explaining that a subpoena "would be tied up in court by the administration until the Committee's writ had expired." ${ }^{52}$ Further, the General Accounting Office ("GAO") declined to appeal after losing on jurisdictional grounds in a suit that it filed to seek information about NEPDG that was separate from the public interest groups' lawsuits cited above. The GAO explained that an appellate decision might further erode its information-gathering powers. ${ }^{53}$

Existing doctrine bears three major characteristics. First, despite the Supreme Court's admonition that its analysis in United States v. Nixon does not necessarily apply to legislative/executive disputes, ${ }^{54}$ the Court and lower courts have since indicated that the Nixon Court's framework, or something much like it, governs any such dispute decided on the merits. ${ }^{55}$ While the Nixon Court rejected the specific claim of executive privilege before it, it deemed executive privilege doctrine itself valid. The Court further

ONLINE, June 24, 2004, http://www.freerepublic.com/focus/f-news/1159384/posts; Paul Courson, GAO Files Unprecedented Suit Against Cheney, CNN.COM, Feb. 22, 2002, http://www.cnn.com/2002/ALLPOLITICS/02/22/enron.gao.lawsuit/index.html.

50. Rice Steadfast in Refusal to Publicly Testify, MSNBC, Mar. 28, 2004, http://www.msnbc.msn.com/id/4601195/.

51. Dan Eggen, White House Holding Notes Taken by $9 / 11$ Commission, WASH. POST, Jan. 31, 2004, at A02.

52. Dana Milbank, Bush's Fumbles Spur New Talk of Oversight on Hill, WASH. POST, Dec. 18, 2005 , at A7.

53. U.S. Gen. ACCOUnting OfFice, Report to Congressional Requestors, Energy Task Force: Process Used to Develop the National Energy Policy 3 n.7 (2003); John W. Dean, GAO's Final Energy Task Force Report Reveals that the Vice President Made a False Statement to Congress, FINDLAW.COM, Aug. 29, 2003, http://www.writ.news.findlaw.com/ dean/20030829.html.

54. See Nixon, 418 U.S. at 712 n.19.

55. See Nixon v. Adm'r of Gen. Servs., 433 U.S. 425, 443, 446-50 (1977); Ass'n of Am. Physicians and Surgeons v. Clinton, 997 F.2d 898, 909 (D.C. Cir. 1993); cf. Senate Select Comm. on Presidential Campaign Activities v. Nixon, 498 F.2d 725, 729, 731-33 (D.C. Cir. 1974) (applying a Nixon-style balancing test shortly prior to U.S. $v$. Nixon to resolve a dispute between the President and a congressional committee). 
suggested that the need for candor in executive branch discussions justifies a presumption in favor of the privilege ${ }^{56}$ and that national security based privilege claims merit even greater protection. ${ }^{57}$ The Court explained that "the silence of the Constitution" with respect to executive privilege is not dispositive, quoting an earlier case's discussion of McCulloch v. Maryland to the effect that "that which [is] reasonably appropriate and relevant to the exercise of a granted power [is] to be considered as accompanying the grant. ${ }^{.58}$ The Nixon Court also noted that the "confidentiality of Presidential communications" bears such a relationship to the President's Article II powers. ${ }^{59}$ Finally, the Court suggested that the presumption favoring a privilege claim is at its strongest and necessitates extreme, possibly absolute, judicial deference where the claim purportedly is grounded in national security interests. ${ }^{60}$

Second, in the context of disputes generated by congressional investigations, such as those generated when subpoenas are issued to executive branch officials, courts have either applied a Nixon-style balancing test ${ }^{61}$ avoided judicial resolution entirely through aggressive use of threshold doctrines such as standing, ${ }^{62}$ or encouraged political resolution but ultimately balanced interests when such resolution was ineffective. ${ }^{63}$ Third, in the context of disputes generated by public access statutes, courts generally have construed statutes narrowly to avoid the separation of powers

56. Nixon, 418 U.S. at $708,713$.

57. Id. at 710-11; see also In re Sealed Case, 121 F.3d 729, 743 n.12 (D.C. Cir. 1997) (stating that the Nixon Court implied that the national security based privilege is "close to absolute").

58. Nixon, 418 U.S. at 705-06 n.16 (quoting Marshal v. Gordon, 243 U.S. 521, 537 (1917) (citing McCulloch v. Maryland, 17 U.S. 316 (1819))).

59. Id. at $705-06$.

60. Id. at 706, 710-11; see also In re Sealed Case, 121 F.3d at 743 n.12.

61. See Senate Select Comm. on Presidential Campaign Activities v. Nixon, 498 F.2d 725, 729, 731-33 (D.C. Cir. 1974).

62. See Walker v. Cheney, 230 F. Supp. 2d 51, 53-54, 65, 68-70 (D.D.C. 2002) (explaining that the standing inquiry must be "especially rigorous" in GAO lawsuit against Dick Cheney because of separation of powers issues and that while Congress might have an interest in receiving the requested information, its statutory authorization to the GAO to conduct investigations was not sufficiently timely or specific to invoke this interest); $c f$. United States v. U.S. House of Representatives, 556 F. Supp. 150, 151-53 (D.D.C. 1983) (refusing to decide merits of executive privilege claim made by EPA head in response to subpoena and House contempt vote because U.S. Attorney had not yet initiated criminal contempt prosecution).

63. A trilogy of district court and circuit court opinions in United States v. ATE'T combined encouragement of political resolution with judicial balancing. While the district court used judicial balancing to decide in the government's favor, United States v. ATE TT, 419 F. Supp. 454, 458-61 (1976), the circuit court issued two opinions, one criticizing the district court for excessive deference to the executive branch and instructing the district court to facilitate interbranch negotiations, United States v. ATE T, 551 F.2d 384, 392-95 (1976), and a subsequent opinion acknowledging that negotiations had not resolved all matters and directing the parties to take steps designed to approach a rough middle ground between their respective positions. United States v. AT\&T, 567 F.2d 121, 123, 130-33 (1977). 
problems that might arise were disclosure by the President or someone close thereto deemed statutorily required. ${ }^{64}$ In all but one case, ${ }^{65}$ this has meant that courts have not ordered public access in the face of executive privilege claims. Instead, courts have construed statutes very narrowly to avoid what courts deem serious separation of powers questions.

These approaches suffer from both analytical and practical problems. Such approaches are problematic analytically to the extent that they assume the ready applicability of the U.S. $v$. Nixon balancing test and rationale to legislative/executive disputes. The Nixon Court was correct to limit its approach to the criminal trial context. Whether the judiciary should recognize an evidentiary privilege that it can weigh against other interests is a very different question from whether judicial and/or executive branch limitations should be imposed on legislatively mandated disclosures. The latter question asks who should have the final word in making political and policy decisions about when it is safe and wise to disclose information. To answer that question one must look to the light shed by Articles I and II on whether information control is a legislative power, an executive power, or a shared power, and, if such light is inconclusive, one should consider whether the Constitution's approach to information control as a whole

64. See Pub. Citizen v. U.S. Dep't of Justice, 491 U.S. 440, 452-67 (1989) (acknowledging that the ABA's Standing Committee on the Federal Judiciary could be deemed "utilized" by the President as the FACA requires under at least "one common sense" interpretation of the word, but looking beyond this interpretation because of serious separation of powers concerns); Ass'n of Am. Physicians and Surgeons v. Clinton, 997 F.2d 898, 903-11 (D.C. Cir. 1993). Citing serious separation of powers concerns, the court decided what it called a close statutory question to deem Hillary Clinton a government officer or employee, making the FACA inapplicable to the health-care task force that she chaired. $I d$.

65. In Nixon $v$. Adm'r of Gen. Servs., the Court considered the facial constitutionality of Title I of the Presidential Recordings and Materials Preservation Act. 433 U.S. 425 (1977). The Act was passed in the wake of an agreement reached by former President Richard Nixon and the Administrator of General Services ("AGS") to give Nixon private title to his extensive archives of presidential recordings and papers (including the infamous White House tapes) and to have the materials deposited near Nixon's California home. Id. The agreement included a provision for the eventual destruction of the White House tapes after a period of several years. Id. at 43032. The Act, designed to abrogate the agreement, prohibited destruction of the Nixon materials and required the AGS to retain control of them. Id. at 433-36. In rejecting Nixon's facial challenge to the statute on executive privilege grounds, the Court invoked United States $v$. Nixon and its balancing test, but deemed any balancing test met. Id. at $443,446-50$. While the Court focused partly on the public interests vindicated by the statute, id. at $452-54$, the crux of its analysis rested on the fact that the Court did not consider the Act to have strongly infringed on executive autonomy. Id at 446-55. First, the privilege was raised by a former President with respect to the materials of a previous administration. Id. at 429. The Court thus deemed the risk of a chilling effect on future Presidents and their advisors relatively minimal. Id. at 448-51. Second, the privilege claim was actively opposed by Gerald Ford (President at the time of the litigation's initiation) and Jimmy Carter (President by the conclusion of the Supreme Court litigation). Id. at 441, 448-51. Third, the Nixon materials remained within the executive branch through the AGS. Id. at 443-44, 451-52. Fourth, the statute explicitly preserved the right to raise privilege claims regarding materials affected by the AGS' regulations. Id. at 444, 450-51, 455 . 
weighs in on the question. Courts have not approached the latter half of such analysis and have only skimmed the surface of the former half, largely assuming that forced disclosure imposes burdens on the President of a constitutional dimension, that courts should try to avoid the difficult separation of powers questions raised as a result, and that judicial resolution on the merits involves a Nixon-style balancing test.

These judicial approaches cause unsurprising practical problems that tend to favor the executive branch. Courts, acknowledging that they are not well equipped to balance the interests at stake in executive privilege clashes, ${ }^{66}$ are prepared to give the executive nearly insurmountable deference in the realm of national security, as represented by the national security aspect of the Nixon Court's reasoning. ${ }^{67}$ Even where national security is not at issue, judicial wariness to second-guess the executive is exemplified both by the Nixon Court's presumption favoring executive privilege claims and by aggressive judicial use of avoidance doctrines. In refusing to endorse relatively intuitive interpretations of public access and investigative authorization statutes, courts may frustrate legislative intent to avoid what courts, using questionable reasoning, deem separation of powers problems. ${ }^{68}$

66. See Ass'n of Am. Physicians E' Surgeons, 997 F.2d at 910.

67. Such deference is fairly standard with respect to national security, given the judiciary's sense that it lacks expertise in this area. National security related deference manifests itself also in judicial treatment of the state secrets evidentiary privilege. See, e.g., Weaver \& Pallito, supra note 3. It also manifests itself in challenges to government classification decisions under the FOIA. See, e.g., Robert P. Deyling, Judicial Deference and De Novo Review in Litigation over National Security Information Under the Freedom of Information Act, 37 VILL. L. REV. 67, 82-87 (1992); Bruce E. Fein, Access to Classified Information: Constitutional and Statutory Dimensions, 26 WM. \& MARY L. REV. 805, $821 \mathrm{n} .72$ (1985); Wells, supra note 5, at 1207-08. For a notable exception in the realm of executive privilege, see ATET II, $551 \mathrm{~F} .2 \mathrm{~d}$ at 392 (criticizing the district court for excessive deference to the executive branch). See supra note 63 for more discussion of the AT\&T opinions.

68. It also is striking that the Supreme Court minimized the relative importance of public access statutes in Cheney v. U.S. Dist. Court, stating:

Even if FACA embodies important congressional objectives, the only consequence from respondents' inability to obtain the discovery they seek is that it would be more difficult for private complainants to vindicate Congress's policy objectives under FACA. And even if, for argument's sake . . FACA's statutory objectives would be to some extent frustrated, it does not follow that a court's Article III authority or Congress's central Article I powers would be impaired. The situation here cannot, in fairness, be compared to Nixon, where a court's ability to fulfill its constitutional responsibility to resolve cases and controversies within its jurisdiction hinges on the availability of certain indispensable information.

Cheney v. U.S. Dist. Court, 542 U.S. 367, 384-85 (2004).

The Court held that Vice President Cheney may make a blanket challenge to all discovery in a FACA litigation rather than making specific challenges to particular discovery requests. Id. at 383-91. The Court cited the separation of powers concerns that the FACA would raise if it applied to a vice-presidential task force and the relative insignificance of any frustration to the FACA's objectives. Id. at 381-91. 


\section{B. MAJOR SCHOLARLY ARGUMENTS}

The major scholarly arguments can be grouped into three categories: those that support a qualified executive privilege whereby the judiciary can apply a balancing test to weigh executive privilege claims against congressional access demands; those that deem executive privilege a "constitutional myth" in light of history, constitutional text, and constitutional structure; and those that advocate that the judiciary refrain partly or completely from resolving executive privilege disputes. While these neat categories oversimplify the literature and exclude some more nuanced views, ${ }^{69}$ they mark an attempt to capture the most prevalent and pronounced divisions among scholars.

Arguments favoring a qualified executive privilege ${ }^{70}$ exemplified by the seminal work of Mark J. Rozell, ${ }^{71}$ partly echo the logic of Nixon $v$. United

69. See generally Peterson, supra note 47 (discussing implications of criminal contempt citations resulting from executive privilege disputes); Peter M. Shane, Legal Disagreement and Negotiation in a Government of Laws: The Case of Executive Privilege Claims Against Congress, 71 MinN. L. REV. 461 (1987) (advocating a negotiation based approach to executive privilege disputes).

70. The text of this Subpart does not discuss arguments for an absolute executive privilege because such arguments have been made predominantly outside of the academic literature, generally prior to the Supreme Court's embrace of a qualified executive privilege in Nixon $\tau$. United States, 418 U.S. 683 (1974). See, e.g., Nixon v. Sirica, 487 F.2d 700, 730, 737-38, 742-45, 750-52 (D.C. Cir. 1973) (MacKinnon, J., concurring in part and dissenting in part) (arguing for absolute privilege with respect to both judicial and congressional requests for information); $i d$. at 768-72, 773-81, 795-99 (Wilkey, J., dissenting) (same); Brief for Respondent, CrossPetitioner Richard M. Nixon, President of the United States, at 48-68, Nixon, 418 U.S. 683 (Nos. 73-1766, 73-1839) [hereinafter Nixon Merits Brief] (arguing for absolute privilege in judicial-executive conflicts but using reasoning broad enough to apply to congressionallegislative disputes); see also, e.g., BERGER, supra note 18, at 8-9 (citing statements of then Attorney General William $\mathbf{H}$. Rehnquist and then Attorney General William P. Rogers in support of absolute executive privilege). At the core of the argument for an absolute executive privilege is the notion that the powers accorded the President in Article II, particularly the vesting of executive power in the President, encompass whatever is "essential" to the effective exercise of such powers. Nixon, 487 F.2d at 750 (MacKinnon, J., concurring in part and dissenting in part); Nixon Merits Brief, supra, at 54 . The premise that presidential information control is so essential underlies this point. Proponents of an absolute executive privilege largely echo the reasoning of the Supreme Court in United States $v$. Nixon in this respect. See Nixon v. Sirica, 487 F.2d at 743 (MacKinnon, J., concurring in part and dissenting in part); see also Nixon Merits Brief, supra, at 63-68. The argument that the President is better situated than a federal judge to determine when secrecy or openness is necessary to the effective execution of the law accompanies this point. See Nixon v. Sirica, 487 F.2d at 795-96 (Wilkey, J., dissenting). Proponents of an absolute privilege also rely on historical arguments similar to those made by proponents of a qualified privilege. See id. at 730-37 (MacKinnon, J., concurring in part and dissenting in part); id. at 775-81 (Wilkey, J., dissenting); Nixon Merits Brief, supra, at 54-59.

71. See generally ROzELL, supra note 9; Rozell, supra note 6. For other academic works supportive of a qualified executive privilege, see, e.g., J. Richard Broughton, Paying Ambition's Debt: Can the Separation-of-Powers Tame the Impetuous Vortex of Congressional Investigations?, 21 WhitTier L. Rev. 797, 821-30 (2000); Dawn Johnsen, Executive Privilege Since United States v. Nixon: Issues of Motivation and Accommodation, 83 MINN. L. REV. 1127, 1127-28, 1131 (1999); Randall K. Miller, Congressional Inquests: Suffocating the Constitutional Prerogative of Executive 
States. That is, Rozell emphasizes the President's need for candid advice ${ }^{72}$ and for leeway in protecting national security and negotiating foreign policy $^{73}$ to fulfill his Article II functions. Rozell also argues that history supports a qualified executive privilege, citing a series of post-ratification disputes that are addressed in Part III.A.1. Rozell further argues that the Constitution's framers and the ratifying generation as a whole envisioned a strong executive with the capacity to keep secrets. ${ }^{74}$ Rozell states, for example, that "two passages from the Federalist Papers support executive branch secrecy": Federalist 70, in which Alexander Hamilton supports a unitary President because "[ [d] ecision, activity, secrecy and despatch [sic] will generally characterize the proceedings of one man in a much more eminent degree than the proceedings of any great number",75 and Federalist 64 , in which John Jay champions the relative "secrecy" and "'despatch [sic]" of the executive branch as an advantage in treaty-making. ${ }^{76}$

It also is worth noting that while Rozell argues that the presumption in judicial balancing "generally should ... favor ... openness," of his discussion reflect the difficulty of applying this presumption. Rozell observes, for example, that "[t]he Court [has] made it clear that when a claim of privilege is made to protect national security or foreign policy deliberations, that claim is often difficult for another branch to overcome in a balancing of constitutional powers. ${ }^{78}$

Arguments against executive privilege are grounded in the structure of Articles I and II, and in history. Raoul Berger, perhaps the best known critic of executive privilege, ${ }^{79}$ emphasizes the extent to which Congress is

Privilege, 81 MINN. L. REv. 631, 635, 684-85 (1997); see also Jeffrey P. Carlin, Note, Walker v. Cheney: Politics, Posturing and Executive Privilege, 76 S. CAL. L. REV. 235, 270-71 (2002).

72. Rozell, supra note 9 , at $46-48$.

73. Id. at 43-46. Rozell also argues that there are internal limits on the scope of Congress's investigative powers. Id. at 48-50. As discussed infra at Part IV.C.1, such arguments are best categorized as distinct from executive privilege claims.

74. Id. at $19-28$.

75. Id. at 24 (quoting THE FEDERALIST No. 70 (Alexander Hamilton) (Clinton Rossiter ed., 1961)).

76. Id. at 24-25 (quoting THE FEDERALIST No. 64 (John Jay) (Clinton Rossiter ed., 1961)).

77. ROzELL, supra note 9 , at $19,156$.

78. Id. at 164 .

79. Interestingly, while the title of Berger's seminal book and much about his tone suggest an outright rejection of executive privilege, see, e.g., BERGER, supra note 18, at 346 ("Congress is entitled to share all the information that pertains to its affairs."); ROzELL, supra note 9, at 49 (characterizing Berger as "believ[ing] that Congress has an absolute, unlimited power to compel disclosure of all executive branch information"), Berger does not reject executive privilege in its entirety. In fact, Berger states that any curtailment of Congress's ability to inquire into executive branch information "is a judicial, not a presidential, function." BERGER, supra note 18, at 31; see also id. at 356 (describing a test that the judiciary should apply to executive privilege claims). Nonetheless, while Berger's arguments technically are directed against an absolute executive privilege, Berger's emphasis clearly is on eviscerating the foundations of this concept rather than on supporting counterpoints that the judiciary might weigh against the 
empowered to control the Executive through the impeachment power, through the Senate's confirmation and treaty ratification roles, and through the legislation that creates, maintains, and effectuates the laws that the President executes. ${ }^{80}$ From this, Berger concludes that Congress is the government's "senior partner" to the President's "junior partner" ${ }^{81}$ and that it would be illogical for the junior partner to have the power to pick and choose the information on which the senior partner might draw to assess the junior partner's activities or otherwise to perform the senior partner's functions. ${ }^{82}$ With respect to history, Berger argues that the founding generation feared a too-powerful executive and that the founders would never have empowered the executive to withhold information. ${ }^{83}$ Berger also cites the post-ratification information disputes cited by Rozell, ${ }^{84}$ concluding that they lend no support to the constitutional legitimacy of executive privilege. ${ }^{85}$

Whereas Berger focuses predominantly on Congress's functional need for information, other executive privilege opponents emphasize the absence of any structural hint of implied presidential powers. The most detailed argument to this effect has been made by Saikrishna Prakash, ${ }^{86}$ whose points overlap in some important respects with an argument made by William Van Alstyne ${ }^{87}$ Prakash details the many respects in which the Constitution leaves the President at the mercy of Congress to determine the nature and efficacy of the President's powers: The President is entitled to no particular budget beyond that granted him by Congress, despite the fact that, "[w]ithout a steady and sufficient supply of funds, the President cannot possibly satisfy his constitutional duties or fulfill the promise of his executive powers." 88 Congress possesses the sole constitutional power to create the armed forces, to call out the militia, and to maintain and provide for the same, thus empowering Congress to leave the President as "Commander-in-Chief . . . of

privilege. Berger's work thus remains an important source of arguments against executive privilege, even if technically directed against an absolute privilege.

80. BERGER, supra note 18 , at 35-37, 49-162.

81. Id. at 7, 13, 346 .

82. Id.; see also Gary J. Schmitt, Executive Privilege: Presidential Power to Withhold Information from Congress, in THE PRESIDENCY IN THE CONSTITUTIONAL ORDER 155 (Joseph M. Bessette \& Jeffrey Tulis eds., 1981) ("The heart of Berger's argument is that the office of the president was never meant to be so independent of Congress as to justify the implied power of executive privilege.").

83. BERGER, supra note 18 , at 49-51, 58-59.

84. Id. at 163-208. See Part III.A.l for this Article's brief discussion of the debate over post-ratification incidents.

85. Id. at 207.

86. See generally Prakash, supra note 8.

87. See generally William W. Van Alstyne, The Role of Congress in Determining Incidental Powers of the President and of the Federal Courts: A Comment on the Horizontal Effect of the Sweeping Clause, 40 LAW \& CONTEMP. PROBS. 102 (Spring 1976).

88. Prakash, supra note 8, at 1154. 
absolutely no one from time to time." ${ }^{\text {"89 }}$ Congress alone can "staff[] the Executive Department" by creating and funding various agencies, offices, and officers, despite the fact that the President surely requires extensive assistance in executing the law. ${ }^{90}$ Given these facts, Prakash asks, "how can we believe that the President has either an inherent or a penumbral right to secret communications? . . . [C] onstitutional structure makes clear that [even more important presidential means] are completely left to Congress to provide." $" 1$

Prakash relies not only on constitutional grants of specific congressional powers but also on implications from the Necessary and Proper Clause, which empowers Congress to "make all Laws which shall be necessary and proper for carrying into Execution the foregoing Powers, and all other Powers vested by this Constitution in the Government of the United States, or in any Department or Officer thereof. ${ }^{92}$ Prakash explains, as William Van Alstyne similarly has argued, that the Necessary and Proper Clause empowers only Congress to provide the means necessary to effectuate its own powers, as well as the powers of the other branches. ${ }^{93}$

Finally, Prakash considers historical evidence. To begin with, Prakash notes that there is no clear pre-ratification support for executive privilege. ${ }^{94}$ Prakash acknowledges Rozell's references to the championing by framers, including in two Federalist Papers, of the President's capacity for secrecy. ${ }^{95}$ Prakash points out, however, that these references "hardly demonstrate that the proposed executive would enjoy a constitutional right to an executive privilege." ${ }^{\circ 6}$ The references instead serve only to describe "one of the common attributes of a single executive. . . In the ordinary course, the President would be able to keep some matter secret." ${ }^{97}$ Whether the President has a constitutional right to keep secrets in the face of congressional requests is another matter. Regarding the post-ratification disputes analyzed by other scholars, Prakash notes the risk of relying too heavily on post-ratification events as evidence of constitutional meaning. ${ }^{98}$ Prakash does, however, examine three conflicts from the Washington administration discussed by Rozell, given the conflicts' relative proximity to ratification. ${ }^{99}$ Much like Berger, Prakash concludes that these incidents do

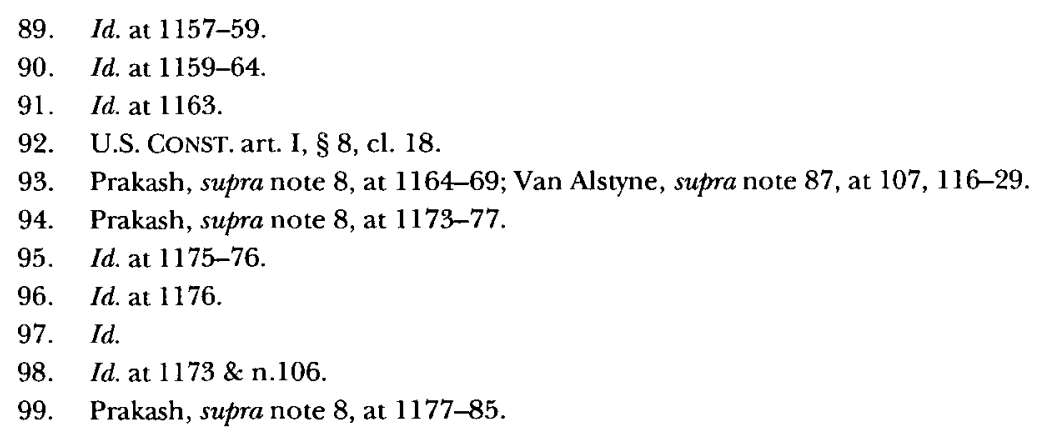


not support the argument for executive privilege and that aspects of the incidents in fact support contrary arguments. ${ }^{100}$

Finally, many scholars argue that the judiciary should exercise restraint in approaching executive privilege disputes. Some argue that the judiciary should treat such disputes as political questions and avoid addressing their merits because executive privilege controversies ask the judiciary to decide "whose political judgment is better-Congress's or the president's, and . . . the judiciary is ill equipped to so decide." ${ }^{101}$ For similar reasons, others advocate judicial intervention only as a last resort. Mark Rozell believes, for example, that most executive privilege controversies should be resolved through the "political ebb and flow of the separation of powers system,"102 although he acknowledges, as discussed above, that functional balancing by the judiciary is necessary in some cases.

With respect to arguments grounded in constitutional text and structure, scholarly support for a qualified executive privilege suffers from largely the same problems that characterize executive privilege doctrine. Scholarly opposition to executive privilege, while laying important groundwork by demonstrating the limited nature of presidential power, suffers from its failure to explore the special constitutional significance of information control. As discussed in Part III, it is not so clear that no small, judicially checkable zone of implied powers attaches to the presidential office. Even if the presidency does contain some implied powers, however, there are reasons to deem information control special from a constitutional perspective and consequently outside the realm of such powers. Indeed, these reasons offer an important alternative basis to reject executive privilege even for those who do not reject implied presidential powers completely. Finally, to the extent that the Constitution demands obedience from the executive branch to statutory openness directives, such directives should be judicially enforced where enforcement is provided statutorily rather than treated as political questions or otherwise judicially avoided.

With respect to historical arguments, those scholars who deem the postratification evidence inconclusive for establishing a constitutional executive privilege have the better of the argument, as discussed briefly in Part III.A.1. With respect to the oft-cited references to secrecy in the Federalist Papers, a

100. Id. See Part III.A.1 for this Article's brief discussion of the debate over post-ratification incidents.

101. Schmitt, supra note 82 , at 181 . Todd Peterson also suggests that, by and large, executive privilege controversies should not be resolved by the judiciary. Peterson, supra note 47 , at $625-31$.

102. Rozell, supra note 6, at 6 . Others take a middle ground similar to that of Rozell, arguing that the judiciary should become no more involved in executive privilege controversies than it already is and that any judicial involvement should focus more on encouraging interparty negotiation than on resolving the merits of the dispute. See, e.g., Bush, supra note 48 , at 745-47; Devins, supra note 47 , at 110, 126-37. 
careful look at the relevant Papers in fact militates against, rather than in favor of, a constitutional executive privilege, as discussed in Part III.B.3.c.

III. SECRECY AND SEPARATED POWERS:

The ARgument for a NeW APProach to EXeCUTIVE Privilege

\section{A. GETTING TO THE NEW APPROACH: OVERLAPPING POWERS AND THE SPECIAL CONSTITUTIONAL SIGNIFICANCE OF INFORMATION CONTROL}

This Part lays the groundwork for understanding the role that the constitutional significance of information control should play in executive privilege analysis. This Part explains, first, that history does not support a constitutional executive privilege. Second, this Part explains that Articles I and II might at first glance suggest that Congress and the President share overlapping powers with respect to textually unnamed tools of law execution, such as information control. Were information control like any other tool of power, a functional balancing approach and some degree of judicial restraint ordinarily might be appropriate. Third, this Subpart introduces the idea that information is not, for constitutional purposes, like any other tool of power. Rather, constitutional analysis suggests that government secrecy, while sometimes necessary, must be kept on a tight political leash to prevent it from becoming a tool of tyranny. Specifically, the Constitution suggests that government secrecy must be shallow and politically checkable.

\section{History and Executive Privilege}

As noted in Part II.B, the two major sources of historical evidence typically offered to support executive privilege doctrine are a series of postratification incidents said to demonstrate an early embrace of executive privilege, and the two passages from the Federalist Papers touting secrecy as a virtue of the unitary President. ${ }^{103}$ The debate over the post-ratification incidents is so well-worn in the scholarly literature that it does not bear much additional discussion. ${ }^{104}$ It suffices to state in the text of this Section with some elaboration via a footnote at the end of this paragraph, that even

103. Cf. Prakash, supra note 8; at 1177 ("Proponents of executive privilege have very little pre-ratification evidence to support their cause.").

104. The relevant post-ratification incidents first were sketched by then Deputy Attorney General William P. Rogers in a 1958 memorandum supporting executive privilege. William P. Rogers, The Papers of the Executive Branch, 44 A.B.A. J. 941, 944 (1958); see also BERGER, supra note 18, at 163-64 (describing the Rogers memorandum and its influence). Raoul Berger responded to the list of incidents, arguing that each incident fails to support a constitutional executive privilege and in some cases supports the opposite conclusion. BERGER, supra note 18, at 163208. Mark J. Rozell cited post-ratification activity in support of executive privilege in his book, Executive Privilege. ROzELL, supra note 9, at 28-43. Saikrishna Prakash most recently echoed Raoul Berger's points that post-ratification activity fails to support a constitutional executive privilege and in some cases supports the opposite conclusion. Prakash, supra note 8 , at 1177-85. 
if one deems post-ratification history a useful tool of constitutional interpretation, the incidents cited in support of executive privilege are inconclusive at best. Problems in the use of the cited incidents include the conflation of arguments based on internal limits on Congress's investigative powers with arguments based on external, executive privilege based limitations; the fact that some cited incidents reflect only self-serving and politically expedient positions taken by administration officials; and the fact that some cited incidents demonstrate no more than the ability of the executive and the legislature to reach political compromises with respect to information requests, an ability inevitably important in information clashes between the branches, regardless of the constitutional legitimacy of executive privilege doctrine. ${ }^{105}$

Executive privilege proponents also cite to statements from the framing and ratifying generation that strongly suggest that the singular nature of the Presidency partly reflects a desire to ensure such qualities as "secresy [sic] ... dispatch . . vigor and energy,"106 qualities to which a multi-member body would be much less conducive. ${ }^{107}$ Alexander Hamilton and John Jay famously referenced these presidential qualities in The Federalist Papers. Hamilton, positing that " $[\mathrm{e}]$ nergy in the executive is a leading character in the definition of good government," explained that "unity is conducive to energy" because "[d]ecision, activity, secrecy, and dispatch will generally characterize the proceedings of one man in a much more eminent degree than the proceedings of any greater number . . ." J08 Jay spoke at length of secrecy's advantages in the treaty-making context, stating:

105. For a discussion focusing solely on the three incidents involving the administration of George Washington, given the more problematic nature of history relatively distant from the ratification period, see Prakash, supra note 8 , at $1184-85$. The first incident is one in which George Washington disclosed all information, albeit after it apparently was opined at a cabinet meeting that the President should refuse to disclose any papers that would injure the public. See, e.g., id. at 1177-79; Rogers, supra note 104, at 944 . The second incident is one in which cabinet members again opined that the President should refuse to disclose information as the public interest demands and in which the President did withhold some information from the Senate, but in which the Senate freely accepted these limitations. The incident thus was resolved in a manner that avoided questions as to whether senatorial acquiescence should occur as a matter of constitutional necessity or of political compromise. See, e.g., HOFFMAN, supra note 1, at 104-18; RozelL, supra note 9, at 30-31; Prakash, supra note 8, at 1179-80. The third incident, in which George Washington refused to disclose information sought by the House of Representatives about a treaty, involved no executive privilege claim but rather a claim that the House is internally limited by the scope of its constitutional powers. Indeed, Washington suggested that he would have turned over the requested information were impeachment at issue, thus suggesting that the House was limited only by the scope of its internal powers and not by executive privilege. BERGER, supra note 18, at 172-73; Prakash, supra note 8, at 1181-83.

106. 1 THE ReCORdS OF THE FEderal CONVENTION OF 1787, at 112 (Max Farrand, ed., Yale Univ. Press 1966); see also id. at 70.

107. See, e.g., id., at 111-12.

108. THE FEDERALIST No. 70 (Alexander Hamilton), supra note 75, at 423-24. 
It seldom happens in the negotiation of treaties, of whatever nature, but that perfect secrecy and immediate dispatch are sometimes requisite... . [T] here doubtless are many ... who would rely on the secrecy of the President, but who would not confide in that of the Senate, and still less in that of a large popular assembly. ${ }^{109}$

As noted earlier, Prakash helpfully puts such statements in perspective, observing that the statements explain only an "attribute[] of a single executive," 110 not that the executive has a constitutional right to exercise that attribute. ${ }^{\text {II }}$ Prakash's insight is an important one. Moreover, careful analysis of these statements and their respective contexts betrays not only their lack of support for a constitutional executive privilege, but also their support for keeping presidential secrecy shallow and politically checkable given the President's special capacity for secrecy and the importance of keeping the President under substantial public and congressional oversight generally.

That the relevant Federalist Papers support, rather than detract from the argument for shallow and politically checkable secrecy is discussed further in Part III.B.3.c. For purposes of the instant Part, it suffices to note that the sparse historical evidence mustered in favor of a constitutional executive privilege fails to support the privilege.

\section{Article I, Article II, Functional Balancing, and Judicial Restraint}

References in Articles I and II to the nature of the legislative power and the executive power also provide no clear answers as to the constitutional status of executive privilege. On the one hand, Prakash's analysis of the President's dependence on the legislature is very important because it demonstrates that the President is meant to be highly constrained by the legislature. Surely, such a constrained figure lacks a categorical right to choose the precise means through which he shall execute the law and serve as Commander-in-Chief. On the other hand, Prakash's argument does not fully address the sometimes murky line between what it is to legislate the scope of presidential power and what it is to execute the law. In terms of information control, it seems that one can credibly argue both that such control is a facet of Congress's power to pass legislation "carrying into Execution" presidential power, ${ }^{112}$ and that once the legislature has given tasks to the executive to effectuate, information control falls within the President's power to effectuate such tasks (e.g., to execute the law). ${ }^{113}$

109. THE FEDERALIST No. 64 (John Jay), supra note 76, at 392.

110. Prakash, supra note 8 , at 1176.

111. See supra notes $95-97$ and accompanying text.

112. U.S. CONST. art. I, $\$ 8, \mathrm{cl} .18$.

113. Cf. Bowsher v. Synar, 478 U.S. 714, 733-34 (1986) (“[O]nce Congress makes its choice in enacting legislation, its participation ends. Congress can thereafter control the execution of 
Furthermore, Prakash's examples of constraints on presidential power involve appropriations or powers otherwise enumerated or strongly implied to be legislative by constitutional text. ${ }^{114}$ While these examples illuminate how constrained the President is meant to be, they do not necessarily resolve the question of to whom information control belongs. A similar point might be made about Raoul Berger's discussion of Congress's oversight role relative to presidential power. ${ }^{115}$

Without more, then, arguments as to the respective natures of Article I and Article II powers could lead one to conclude that information control falls within a "zone of twilight" between executive and legislature, ${ }^{116}$ and that inter-branch tugs of war regarding such control are best resolved on case by case bases through functional balancing tests or treated as political questions. Furthermore, on a practical note, much existing doctrine and scholarship embraces the notion of implied presidential powers and privileges. ${ }^{17}$ It is thus important to demonstrate that information control is different than other tools of power and that it cannot constitute an implied presidential power or privilege even if such powers and privileges exist.

\section{The Role of Information Control's Constitutional Significance}

Starting from the assumption that tugs of war as to implied presidential powers often are resolved best through functional balancing or as political questions, it becomes important to consider whether information control is different from other tools of power in a way that directs a unique conclusion about it. In fact, information and information control have very special constitutional significance. Reliance on openness as an operative norm and faith in openness as a democratic salve can be detected throughout the Constitution. Specifically, constitutional text and structure suggest a faith in openness between the political branches and between such branches and the people. At the same time, constitutional structure, text, and history also suggest an understanding that government secrecy sometimes is a necessary evil. Ultimately, text, structure, and history suggest that the means of

its enactment only indirectly ... ."); Youngstown Sheet \& Tube Co. v. Sawyer, 343 U.S. 579, 637 (1952) (Jackson, J., concurring) (referring to "zone of twilight" in which "distribution [of power between President and Congress] is uncertain").

114. See Prakash, supra note 8, at 1154-64. While Prakash's last example, that of "Creating Officers and Departments," is not explicitly listed in Article I, Section 8, the legislative nature of any such creation is strongly implied by the related necessity to appropriate funds and by references in the Appointments Clause to the establishment "by Law" of "Officers of the United States." U.S. CONST. art. II, § 2, cl. 2.

115. Berger seems implicitly to recognize this point in suggesting that information control disputes should be resolved judicially. See supra note 79.

116. See Youngstown Sheet $\mathcal{E}$ Tube Co., 343 U.S. at 637 (Jackson, J., concurring).

117. See, e.g., supra notes 54-60 and accompanying text (discussing U.S. v. Nixon); supra note 70 and accompanying text (citing scholarly arguments supporting a qualified executive privilege); see also, e.g., Nixon v. Fitzgerald, 457 U.S. 731, 748-58 (1982). 
reconciling these points is to ensure that any government secrecy remain a politically controllable tool of the people and their representatives. Specifically, text, structure, and history suggest that, to keep government secrecy within the ultimate control of the people, and hence non-tyrannical, the very fact of such secrecy must remain shallow and politically checkable.

\section{Elaboration on the Shallow/Deep Secrecy Distinction and Its Constitutional Relevance}

As noted earlier, this Article uses the phrase "shallow and politically checkable" as shorthand for the status that the Constitution demands of political branch secrecy. ${ }^{118}$ This status is one of subordination to legislative openness requirements. Such subordination equates to shallowness and political checkability in the two senses described earlier: It subjects secrecy to policies that themselves are open, and it subjects specific secrets to the possibility of being made shallow or even revealed through such policies' effectuation.

Another way to understand this point is to envision secrecy as encompassing a spectrum of categories that includes very shallow, minimally shallow, minimally deep, and very deep. Subordinating secrecy to broader openness legislation keeps secrecy "shallow and politically checkable" by creating conditions conducive to "minimally shallow" and "very shallow" secrecy and antagonistic to "minimally deep" and "very deep" secrecy. A very shallow secret is a secret, the existence and basic nature of which are known, even if the precise information that comprises the secret itself is not disclosed. An example of a very shallow secret is the content of the Nixon White House tapes: as noted earlier, the tapes' existence came to light due to congressional testimony by former presidential aide Alexander Butterfield. ${ }^{119}$ Between the time that the fact of the tapes was disclosed and the tapes themselves were released, the tapes were a very shallow secret. Another example of a very shallow secret is the August 6, 2001 Presidential Daily Briefing ("PDB") that was the subject of much public, congressional, and agency speculation prior to its declassification. The PDB first was sought unsuccessfully by the Joint Inquiry before ultimately being disclosed to the 9/11 Commission and declassified. The general subject matter of the PDBthe possibility of an airline hijacking masterminded by Osama Bin Ladenwas known prior to its disclosure. Before its disclosure, then, the PDB was a very shallow secret. ${ }^{120}$

There is some overlap between the next two points on the spectrum: minimally shallow secrecy and minimally deep secrecy. Both might be characterized as states of affair in which the existence of at least some secrets

118. See supra page 105-07.

119. See supra notes 15-16 and accompanying text.

120. See, e.g., Dean, supra note 45; Isikoff \& Hosenball, supra note 45; Strohm, supra note 38. 
is not known or easily discoverable, but in which the policy of secrecy itself is known. From this perspective, the distinction between minimally shallow secrecy and minimally deep secrecy is one of degree, as measured by the extent to which certain factors are present or absent. These factors include: (1) the high visibility of secrecy policies; (2) the relatively easy ability to alter secrecy policies through political channels; and (3) the relatively easy ability to effectuate policies of openness (e.g., the relatively easy ability on the part of the public to invoke public access statutes or on the part of congresspersons to invoke statutory investigative authority).

A state of very deep secrecy is one in which even secrecy policies generally are unknown.

The imprecision of the term "shallow secrecy" necessarily complicates the meaning of the statement that government secrecy should be "shallow and politically checkable." A more precise way to frame the point is that the apparatus for information control between the branches should be such as to funnel information, to the extent possible, into a state of minimal to very shallow secrecy and away from a state of minimal to very deep secrecy. This suggests, again, that statutory policies of openness against the executive branch should be final as a constitutional matter and thus enforceable with relative ease and reliability. This point is elaborated on in Part IV. As a foundational matter, however, Part B explores the constitutional bases of the argument that political secrecy should be "shallow and politically checkable," meaning that it should exist within a framework that facilitates minimal to very shallow secrecy and protects against minimal to very deep secrecy.

\section{B. THE CONSTITUTIONAL FOUNDATIONS OF THE ARGUMENT FOR SHALLOW AND POLITICALLY CHECKABLE SECRECY}

1. Openness as the Presumptive Constitutional Norm in Inter-Branch and Government-Populace Relations

\section{a. Popular Sovereignty}

The provision of direct popular sovereignty for the House of Representatives and a framework for indirect popular sovereignty for the Senate and the President in the original Constitution suggest the necessity of presumptive openness in government. ${ }^{121}$ Popular sovereignty would not have much meaning without a norm of openness as to governors' activities, without which governors could easily manipulate the people through information control. Indeed, Charles Black has argued that free information flow is so crucial to the Constitution's structure that free speech would have

121. U.S. CONST. art. I, § 2, cl. 1; id. art. I, § 3, cl. 1; id. art. II, § 1, cl. 2-3. 
to be protected even if the First Amendment did not exist. ${ }^{122}$ That popular sovereignty must mean informed popular sovereignty is suggested also by the philosophical premises that underscore popular control. As Mark Fenster notes, sentiments favoring government transparency can be found "in the classic liberalism of Locke, Mill, and Rousseau, in both Benthamite utilitarian philosophy and Kantian moral philosophy."123

While the original Constitution did not provide for direct popular control in the case of the Senate and the President, it provided for indirect popular control in both cases, with state legislatures picking Senators and directing the means of choosing electors to select the President. Founding era statements assume that this framework is one of ultimate popular control for each federal branch. ${ }^{14}$ Alexander Hamilton, writing in Federalist 84, evinced this assumption and combined it with further assumptions to the effect that government information would flow freely between the federal government, state legislators with direct responsibility for electing Senators and for choosing the means of presidential elector selection, and the populace responsible for electing House members and state legislators. Hamilton notes:

The executive and legislative bodies of each State will be so many sentinels over the persons employed in every department of the national administration; and as it will be in their power to adopt and pursue a regular and effectual system of intelligence, they can never be at a loss to know the behavior of those who represent their constituents in the national councils, and can readily communicate the same knowledge to the people. Their disposition to apprise the community of whatever may prejudice its interests from another quarter may be relied upon, if it were only from the rivalship of power. ${ }^{125}$

Reflecting an understanding of government openness as a precondition of popular sovereignty more generally, Hamilton also envisioned a messenger role for citizens who lived closest to state capitols:

It ought also to be remembered that the citizens who inhabit the country at and near the seat of government will, in all questions

122. Charles L. Black, JR., Structure and Relationship in Constitutional LaW 35-51 (1969).

123. Mark Fenster, The Opacity of Transparency, 91 IOWA L. REv. 885, 895-96 (2006) (internal citations omitted); see also HOFFMAN, supra note 1, at 11-13.

124. See, e.g., ThE FEDERalist No. 70 (Alexander Hamilton), supra note 75, at 429 (referring to popular control over the President); 1 THE RECORDS OF THE FEDERAL CONVENTION, supra note 106, at 49-50 (referring to James Madison as an "advocate for the policy of refining the popular appointments by successive filtrations"); id. at 359 (noting that John Rutlidge "could not admit the solidity of the distinction between a mediate \& immediate election by the people").

125. THE FEDERALIST No. 84, at 516-17 (Alexander Hamilton) (Clinton Rossiter ed., 1961). 
that affect the general liberty and prosperity, have the same interest with those who are at a distance, and that they will stand ready to sound the alarm when necessary, and to point out the actors in any pernicious project. The public papers will be expeditious messengers of intelligence to the most remote inhabitants of the Union. ${ }^{126}$

The evolution within the United States toward direct, rather than indirect, popular sovereignty further strengthens the argument for presumptive government openness. Senators have been elected directly by the people since the Seventeenth Amendment was ratified in 1913. ${ }^{127}$ And while the electoral college still exists, "the states (working in conjunction with political parties) have all (more or less) effectively constrained their electoral college members to follow a popular presidential vote in the state."128

\section{b. The First Amendment}

If Charles Black is correct and protection for free speech is implicit in constitutional structure, ${ }^{129}$ the existence of the First Amendment nonetheless accentuates the importance of free information flow to the Constitution's design. The point is not that the First Amendment provides a direct means to access the information at issue in executive privilege claims. As I have suggested elsewhere, the First Amendment, while providing direct access to some government information, ${ }^{130}$ generally does not provide access to the type of information at issue in executive privilege disputes. ${ }^{131}$ The point rather is that the First Amendment is further evidence that the Constitution strongly values free information flow as a presumptive norm in a system based on self-government. Such evidence, like other constitutional indicia of this norm, impacts our understanding of information control between the branches, including of Congress's ability to control presidential secret-keeping.

Indeed, the First Amendment's text, particularly its broad free speech and free press clauses, and its explicit protection for petitioning the government, evinces a presumptive embrace of free information flow as part of self-government's structure. This intuitive reading of text is bolstered also by reference to widely accepted tenets of free speech theory. As I have

126. Id. at 517 .

127. U.S. CONST amend. XVII.

128. Robert W. Bennett, Democracy as Meaningful Conversation, 14 ConsT. Comm. 481,515 (1997).

129. See supra note 122.

130. See Kitrosser, supra note 14, at 102-12.

131. Id. at 99-100, 130-36 (arguing that significant First Amendment access rights should not attach to proceedings or information that roughly could be deemed "political" in nature). 
elaborated elsewhere, the ability of the people to oversee and to check their governors is "at least an important part of the justification for free speech." ${ }^{\prime 32}$ This is a point widely accepted throughout free speech case law and scholarship. ${ }^{133}$ Indeed, it is from this premise that the Supreme Court reached the insight that the First Amendment embodies limited rights to access government information. ${ }^{194}$ The point, again, is not that the First Amendment is a direct source of access to the information at issue in most executive privilege disputes. But understanding that government secrecy in some cases can so undermine the preconditions of free speech as to violate the First Amendment highlights the constitutional presumption of openness as an operative norm. This presumption, again, is of no small importance in interpreting the Constitution's structural directives as to information control between the political branches.

\section{c. The Public, Dialogic Nature of the Legislative, Treaty-Approval, and Nomination Processes}

Finally, the relatively public and dialogic nature of the legislative, treatyapproval, and nomination processes again reflects a Constitution built on a presumptive faith in openness and dialogue between the political branches and between those branches and the people. As Laura Fitzgerald has observed, analysis of these processes reveals federal political branches structured around mutual obligations "to speak and to listen" to one another. ${ }^{135}$ Furthermore, this information flow is expected to find its way to the people. ${ }^{136}$

With respect to the legislative process, the Constitution requires that a majority of the House of Representatives and of the Senate approve a bill. ${ }^{137}$ This requirement exists against a general expectation of deliberation and relative openness in the proceedings of the House and the Senate. ${ }^{138}$

132. Id. at 128; see also id. at 126 (introducing self-government and government "checking" theories of free speech value, the former most closely associated with Alexander Meiklejohn and the latter with Vincent Blasi).

133. See, e.g., Thornhill v. Alabama, 310 U.S. 88, 95, 101-02 (1940); Kitrosser, supra note 14, at 126-29 (arguing that self-government and its underlying theoretical premises form part of virtually every major theory of free-speech value); Alexander Meiklejohn, The First Amendment Is an Absolute, 1961 SUP. CT. REV. 245, 256, 263 (1961).

134. See, e.g., Globe Newspaper Co. v. Superior Court of Norfolk County, 457 U.S. 596, 60305 (1982).

135. Laura Fitzgerald, Cadenced Power: The Kinetic Constitution, 46 DukE L.J. 679, 767 (1997); see also id. at 761-67.

136. See id. at 761-67.

137. U.S. ConST. art. I, \& 7, cl. 2.

138. The requirement in Article I, section 5, clause 3 that " $[\mathrm{e}] \mathrm{ach}$ House shall keep a Journal of its Proceedings, and from time to time publish the same" partly exemplifies this expectation, though the clause allows Congress to exempt "such parts as may in their Judgment require Secrecy." U.S. CONST. art. I, $\$ 5, \mathrm{cl}$. 3 . The pre-founding perception of openness in state and federal legislatures and the founders' apparent understanding of a very limited scope for 
Furthermore, once each chamber approves a bill, the bill must be shared with the President who concurs and signs the legislation or who, if he disagrees, not only must return the legislation to the chamber in which it originated but must do so "with his Objections." 39 The relationship of this requirement to the process' public nature is particularly clear in light of the mandate that the relevant chamber "enter the Objections at large on their Journal." ${ }^{40}$ Furthermore, the President's objections ultimately must be shared with both congressional chambers and the bill becomes law only if two-thirds of each chamber, again against a presumptive backdrop of dialogue and relative openness, approves it. ${ }^{141}$ In a final nod to the process' public nature, "the Votes of both Houses shall be determined by yeas and Nays, and the Names of the Persons voting for and against the Bill shall be entered on the Journal of each House respectively." 142

While the procedures for making treaties and appointing public officials are less elaborate and inclusive than the legislative process, the Constitution nonetheless ensures that these processes are multilateral and contain dialogue-driven checks. The President may only make treaties with the "Advice and Consent of the Senate" and with the concurrence of "two thirds of the Senators present."143 And while he may nominate "Ambassadors, other public Ministers and Consuls, Judges of the supreme Court, and all other Officers of the United States," he may appoint the same only with the "Advice and Consent of the Senate." 144 These provisions not only incorporate dual-branch review and concurrence, but explicitly require dialogue and consultation in the form of "Advice," much like the dialogueinfused requirements for legislating.

Alexander Hamilton emphasized the positive impact on public knowledge of the shared role between the Senate and the President in appointments. Hamilton explained:

[A]s there would be a necessity of submitting each nomination to the judgment of an entire branch of the legislature, the circumstances attending an appointment, from the mode of conducting it, would naturally become matters of notoriety, and the public would be at no loss to determine what part had been performed by the different actors. ${ }^{145}$

the secrecy exception of Article I, Section 5, Clause 3 further evidence this expectation. See, e.g., HOFFMAN, supra note 1, at 28-29, 35-38.

139. U.S. CONST. art. I, $\S 7$, cl. 2.

140. Id. The journal is, of course, presumptively public. See supra note 138.

141. U.S. CONST. art. I, $\$ 7$, cl. 2.

142. Id.

143. Id. art. II, $\$ 2$, cl. 2.

144. Id.

145. The Federalist No. 77, at 461 (Alexander Hamilton) (Clinton Rossiter ed., 1961). 
Equally striking is Hamilton's negative portrayal of the comparatively insular nature of officer nominations in the state of New York and the resulting impact on public knowledge:

The council of appointment consists of from three to five persons, of whom the governor is always one. This small body, shut up in a private apartment, impenetrable to the public eye, proceed to the execution of the trust committed to them. It is known that the governor claims the right of nomination upon the strength of some ambiguous expressions in the Constitution; but it is not known to what extent, or in what manner he exercises it; nor upon what occasions he is contradicted or opposed. The censure of a bad appointment, on account of the uncertainty of its author and for want of a determinate object, has neither poignancy nor duration. ${ }^{146}$

Hamilton drew like conclusions regarding the shared Senatepresidential role in treaty formation. In addition to the advantages of the "numbers and characters of those who are to make [treaties,]" Hamilton noted that any misbehavior by the Executive surely would be reported by the Senate to the people: "the usual propensity of human nature will warrant us in concluding that there would be commonly no defect of inclination in the body to divert the public resentment from themselves by a ready sacrifice of the authors of their mismanagement and disgrace..147

Discussing the shared nature of legislative power, James Madison similarly emphasized the connection between power sharing, dialogue, and the knowledge and ultimate control of the people. Madison explained, for example, that before the Senate could cause a revolution based on corruption, "the Senate . . must in the first place corrupt itself; must next corrupt the State legislatures, must then corrupt the House of Representatives, and must finally corrupt the people at large."148

\section{The Need for Occasional Secrecy}

Of course, not every aspect of government activity can or should be fully open to the public. Government secrecy is often, but certainly not always, bad policy. ${ }^{149}$ The Constitution's framers recognized and provided for occasional needs that might arise for government secrecy. With the myriad ways in which constitutional structure reflects a need for and philosophy of openness, however, it is striking how relatively minute support for government secrecy, let alone executive branch secrecy, is in the

146. Id.

147. The Federalist No. 66, at 407 (Alexander Hamilton) (Clinton Rossiter ed., 1961).

148. The Federalist No. 63, at 388 (James Madison (cited by Rossiter as "Probably Madison")) (Clinton Rossiter ed., 1961).

149. See infra Part V. 
Constitution. This Part discusses the two major ways in which the Constitution reflects some need for and expectation of government secrecy. This Section also discusses the fact that the Constitution itself was drafted in secret. Part III.B.3 elaborates further on each example and explains that each example reflects no more than a constitutional embrace of shallow and politically checkable secrecy.

The Constitution's only textual reference to secrecy occurs in Article I, section 5 , clause 3 , which states that:

Each House shall keep a Journal of its Proceedings, and from time to time publish the same, excepting such Parts as may in their Judgment require Secrecy; and the Yeas and Nays of the Members of either House on any question shall, at the Desire of one fifth of those Present, be entered on the Journal. ${ }^{150}$

Hence, each Chamber's journal/openness requirement is juxtaposed with discretion to circumvent the requirement when the relevant Chamber deems it necessary.

While there is no textual mention of executive branch secrecy, founding era statements suggest that the singular nature of the Presidency partly reflects a desire to ensure such qualities as "secresy [sic] . . . dispatch . . vigor and energy," would be less conducive. ${ }^{152}$ Alexander Hamilton and John Jay famously reference these presidential qualities in The Federalist Papers, as noted above and as discussed further below. ${ }^{153}$

Finally, it bears noting that the Constitution itself was drafted in secret. ${ }^{154}$ The Philadelphia Convention in which the Constitution was drafted adopted a rule of secrecy covering the convention proceedings. ${ }^{155}$ The rule of secrecy was the source of some controversy and debate both within and beyond the convention walls. ${ }^{156}$ Thomas Jefferson famously lamented the secrecy rule, stating, "I am sorry they began their deliberations by so abominable a precedent as that of tying up the tongues of their

150. U.S. CONST. art. I, $\$ 5$, cl. 3.

151. See, e.g., 1 THE RECORDS OF THE FEDERAL CONVENTION, supra note 106, at 112 (quoting George Mason: "[T] he chief advantages which have been urged in favor of unity in the Executive, are the secresy [sic], the dispatch, the vigor and energy . . "); id. at 70 (quoting James Wilson to similar effect).

152. See, e.g., id. at 111-12.

153. See supra Part III.A.1; infra Part III.B.3.c.

154. See generally 1 THE Records of THE Federal CONVENTION, supra note 106, at xi-xiv; HOFFMAN, supra note 1, at 20-24.

155. Vasan Kesavan \& Michael Stokes Paulsen, The Interpretive Force of the Constitution's Secret Drafting History, 91 GEO. L.J. 1113, 1115 (2003).

156. See, e.g., 2 ThE Records of THE Federal Convention, supra note 106, at 18; 3 THE RECORDS OF THE FEDERAL CONVENTION, supra note 106, at 173-74, 190-91; HOFFMAN, supra note 1 , at 20-24. 
members. [N]othing can justify this example but the innocence of their intentions, \& ignorance of the value of public discussions." ${ }^{\text {5157 }}$ Others insisted that the secrecy rule was necessary. James Madison, for example, stated that "No Constitution would ever have been adopted by the Convention if the debates had been public." 158 And Alexander Hamilton insisted: "Had the deliberations been open while going on, the clamours of faction would have prevented any satisfactory result. Had they been afterwards disclosed [during the ratification period], much food would have been afforded to inflammatory declamation." 159 The members of the convention eventually handed the convention notes over to George Washington, though they left the ultimate decision as to publication or secrecy to "Congress, if ever formed under the Constitution." ${ }^{\text {"160 }}$ In 1818, Congress ordered the notes printed for public release. ${ }^{161}$

3. Reconciling the Two Elements:

Keeping Secrecy Shallow and Politically Checkable

\section{a. The Logical Place of Shallow and Politically Checkable Secrecy in Constitutional Structure}

The Constitution's structural reliance on openness and its reflection of the need for occasional secrecy can be reconciled through the realization that secrecy is but a tool that government may use to effectuate its purposes. Because it is a tool that poses unique dangers of being used tyrannically and of being undiscoverable when so used, strenuous efforts must be made to keep the tool within the sight of its ultimate owners, the people. The logical means of keeping the tool so in check are mechanisms designed to help ensure secrecy's shallowness and political checkability.

The remainder of this Part explains that the structural and historical embraces of secrecy described in Part III.B.2 evince support for no more and no less than shallow and politically checkable secrecy.

\section{b. Article I, Section 5}

Recall that the Constitution's only textual reference to secrecy is in Article I, section 5, which states:

Each House shall keep a Journal of its Proceedings, and from time to time publish the same, excepting such Parts as may in their

157. 3 THE RECORDS OF THE FEDERAL CONVENTION, supra note 106 , at 76.

158. HOFFMAN, supra note 1 , at 21 .

159. Id.

160. 2 The Records of THE Federal Convention, supra note 106, at 648; accord 3 THE RECORDS OF THE FEDERAL CONVENTION, supra note 106, at 423-24, 425; Kesavan \& Paulsen, supra note 155 , at 1115 .

161. 1 THE RECORdS OF THE FEDERAL CONVENTION, supra note 106, at xi-xii. 
Judgment require Secrecy; and the Yeas and Nays of the Members of either House on any question shall, at the Desire of one fifth of those Present, be entered on the Journal. ${ }^{162}$

What is most significant about this provision is not its acknowledgment of the need for some government secrecy, nor even the bare fact that only Congress is explicitly empowered to keep secrets. ${ }^{163}$ What makes this provision so significant is that it suggests a choice to accord an explicit secret-keeping power only to the branch that will logistically and politically find it most difficult to keep secrets. Additionally, this power is couched as an exception to a general norm of openness. This suggests an understanding that when government secrecy occurs, it should be rare, difficult to engage in, and sufficiently exceptional as to be detectible and, hence, shallow.

Article I, section 5, clause 3 was framed against a backdrop of presumptive legislative openness, as the Continental Congress had operated in relative transparency for at least a decade by the time of the framing. As Daniel Hoffman notes, "In principle, any information laid befcre Congress was a matter of public record unless placed under specific injunction of secrecy; and the votes and official acts of Congress were likewise, unless entered in a separate secret journal reserved for matters of delicate nature. ${ }^{164}$ Expectations of legislative openness were also reflected in the controversy among the Philadelphia Convention-goers and in the ratification process over Article I, section 5, clause 3. As Hoffman explains, both proponents and opponents of the provision agreed that secrecy should be "limited to the most highly sensitive military and diplomatic affairs; they differed only as to whether the Constitution made this sufficiently clear." ${ }^{165}$ And expectations of legislative openness also were borne out in practice: the House of Representatives opened its proceedings to the public and the press from a very early stage. ${ }^{166}$ The Senate was more reticent and operated behind closed doors for several years before ultimately giving in to political pressure and opening its doors as well. ${ }^{167}$

The very framing of the congressional secrecy provision as an exception to an openness mandate, combined with the expectation that a large and deliberative legislative body generally will operate in sunlight, suggests a particular means of balancing any need for government secrecy against the necessities of meaningful popular oversight and the dangers of government

162. U.S. CONST. art. I, $§ 5, \mathrm{cl} .3$.

163. But see BERGER, supra note 18, at 42 (relying on this textual exclusivity).

164. HOFFMAN, supra note 1 , at 14

165. Id. at 37; see also id. at 28-29, 35-38; 2 THE RECORDS OF THE FEDERAL CONVENTION, supra note 106 , at 260.

166. HOFFMAN, supra note 1 , at $48-50,79$.

167. Id. at 55-58, 60, 67-69, 81-83, 84-88. 
opacity. Specifically, these factors suggest a framework wherein final decisions as to political secrecy are trusted only to bodies likely to face internal and external pressures against such secrecy. Internal pressures are more likely to be generated in an inherently deliberative body, such as the legislature or a chamber thereof, than in an intrinsically insular body characterized by a single person's capacity for unilateral action. And both internal and external pressures are more likely to be generated where secrecy is exceptional, where the body itself thus is likely to treat secretkeeping as a consciously chosen course of action subject to debate, and where the public is more likely to notice an exceptional instance of "doorclosing."

Article I, section 5, clause 3 thus by no means evinces blanket constitutional approval of government secrecy. To the contrary, its status as the only textual grant of secret-keeping power suggests that such power may be appropriate only where conditions exist to facilitate shallow, rather than deep, secrecy. Such conditions inhere where secrecy is relatively likely to constitute a detectible policy choice and thus to be subject to debate between political actors and between such actors and the people.

\section{c. The Unitary Presidency}

The notions of deep and shallow secrecy also provide a useful conceptual framework for understanding the relationship between the unitary presidency and government secrecy. As noted earlier, members of the founding generation extolled the capacity for secret-keeping of a single President. At the same time, they extolled the relative transparency, upon investigation, of a single person's doings. This suggests a compromise between the advantages of presidential secrecy and the risk of tyranny that such secrecy poses: the President can use his unique capacity for secretkeeping but such use must remain on a relatively short political leash.

As noted earlier, Alexander Hamilton famously stated that presidential " $[u]$ nity is conducive to energy" because "[d]ecision, activity, secrecy, and dispatch will generally characterize the proceedings of one man in a much more eminent degree than the proceedings of any greater number . . ."168 Yet Hamilton, in the same Federalist Paper in which he made this statement, followed the statement with an approving explanation of the responsibility and potential transparency of a unitary President. Hamilton argued that "multiplication of the executive adds to the difficulty of detection," including the "opportunity of discovering [misconduct] with facility and clearness." One person "will be more narrowly watched and most readily suspected." ${ }^{169}$

168. The FEDERALIST No. 70 (Alexander Hamilton), supra note 75, at 424 .

169. Id. at 427-30. 
Similar observations were made at the Philadelphia Convention ${ }^{170}$ and during the ratification period. ${ }^{171}$ For example, William Davie explained in the North Carolina ratification debate:

With respect to the unity of the Executive, the superior energy and secrecy wherewith one person can act, was one of the principles on which the Convention went. But a more predominant principle was, the more obvious responsibility of one person. It was observed that, if there were a plurality of persons, and a crime should be committed, when their conduct was to be examined, it would be impossible to fix the fact on any one of them, but that the public were never at a loss when there was but one man. ${ }^{172}$

Discussions of the unitary President's responsibility and potential transparency are subsets of more general observations regarding checks and balances on presidential power and their impact on intra-governmental information sharing and public knowledge. Such checks and balances include the President's ultimate dependence on the people and the contingency of most presidential action on congressional oversight and approval. The safety that inheres in these checks was observed by the founders, particularly in contrasting the limited and dependent power of the President with the boundless power of monarchs. ${ }^{173}$

John Jay tied the notion of shared power to intra-governmental and public oversight in his discussion, cited earlier, of the treaty power. ${ }^{174}$ After referring approvingly to the President's capacity for secrecy during treaty negotiations, ${ }^{175}$ Jay dismissed concerns about corruption, deeming it improbable "that the President and two thirds of the Senate will ever be capable of such unworthy conduct." ${ }^{\text {"76 }}$ Jay further reassures that "in such a case, if it should ever happen, the treaty so obtained from us would, like all other fraudulent contracts, be null and void by the law of nations." ${ }^{177}$ Finally, should all other safeguards fail, Jay explains that "motive to good behavior is amply afforded by the article on the subject of impeachments." 178 Jay's references to senatorial, bi-cameral (through impeachment), and international oversight assume a capacity on the part of those with oversight

\footnotetext{
170. See, e.g., 1 THE RECORdS OF THE FEDERAL CONVENTION, supra note 106, at 74, 254.

171. See, e.g., HOFFMAN, supra note 1, at 29-32.

172. Id. at 30 (quoting 3 THE RECORDS OF THE FEDERAL CONVENTION, supra note 106, at
} $347)$.

173. See, e.g., THE Federalist No. 69, at 415-23 (Alexander Hamilton) (Clinton Rossiter ed., 1961); $c f$., e.g., 1 THE RECORDS OF THE FEDERAL CONVENTION, supra note 106, at 70-71, 85$87,98-105$.

174. See supra text accompanying note 109 .

175. See supra Part III.B.2.

176. THE FEDERALIST NO, 64 (John Jay), supra note 76, at 395.

177. Id.

178. Id. at 396. 
power to uncover information relating to possible presidential corruption in the treaty-making process. Furthermore, insofar as Jay connects senatorial and presidential incentives for good behavior with the possibility of public rebuke, citing concerns about "honor," "reputations," and "disgrace," 179 he assumes that an investigating and punishing Congress can make damaging information public and that this possibility will incentivize good behavior. This is consistent with Alexander Hamilton's observation, noted earlier, that the Senate will not hesitate to shift public blame to the President for problems in the making of treaties. ${ }^{180}$

As exemplified by Jay's discussion, general assurances regarding popular oversight of the President and the shared nature of political power encompass assumptions that presidential secrecy powers must be subject to questioning and line drawing by Congress. These assumptions similarly are encompassed in observations regarding the heightened responsibility and potential transparency of the unitary presidency. In short, the founders acknowledged the President's capacity for secret keeping and saw such capacity as an advantageous, even necessary, trait. But they similarly recognized the capacity for abuse inherent in such power and appeared to assume that congressional oversight would keep such capacity under tight political control by threatening to expose the existence or even content of secrets.

\section{d. Constitutional Convention Secrecy}

It also is interesting to note that the secrecy of the Constitution's drafting, ${ }^{181}$ though hardly a high point in the history of open government, approaches the conditions for secrecy described in this Part and thus is largely consistent with the limited embrace of shallow, checkable secrecy suggested by Article I, Section 5. Certainly, the Philadelphia Convention was a deliberative forum. And as noted earlier, the imposition of secrecy was subject to debate both within and beyond the convention walls. ${ }^{182}$ Furthermore, those who ratified the Constitution were aware of its secret drafting history and had the opportunity to reject the Constitution on that basis. ${ }^{183}$

179. Id.

180. See supra note 147 and accompanying text.

181. For a general discussion of the Constitution's secret drafting history, see, e.g., HOFFMAN, supra note 1, at 20-24; 1 THE RECORDS Of THE FEDERAL CONVENTION, supra note 106, at xi-xiv; Kesavan \& Paulsen, supra note 155, at 1115.

182. See, e.g., Hoffman, supra note 1, at 20-24; 2 THE Records OF THE Federal CONVENTION, supra note 106, at 18; 3 THE RECORDS OF THE FEDERAL CONVENTION, supra note 106 , at 173-74, 190-91.

183. See, e.g., 3 THE Records of THE Federal CONVEnTION, supra note 106, at 173-74, 191; HOFFMAN, supra note 1, at 20-24. 
The secrecy in which the Constitution was drafted also suggests another lesson relevant to executive privilege doctrine. Specifically, the secret drafting of a document so steeped in openness principles may simply reflect a fact of human nature-the frequent divide between what people profess and what they do. This point is further demonstrated by historical misuses and abuses of executive branch secrecy. ${ }^{184}$ This observation of course is reflected in the rules-based nature of the Constitution, in its embrace of government openness as a general rule, and in its limited embrace of secrecy as a politically controllable tool. Daniel Hoffman puts the lesson well, explaining:

[T] he reticence of the framers can be viewed in light of their hope to design a system that would win acceptance and function properly in spite of the shortcomings of those who created it and those who would succeed them.... [T] he Founding Fathers were eminently realistic about the temptations to which political man is subject, and they claimed no personal immunity. The genius of constitutionalism lay in its honest confrontation of such realities and its attempt to contain them by resort to checks and balances, fair procedures, and public accountability. The merit of the framers' design deserves to be judged without reference to the impurities of personal motives or the vicissitudes of the negotiating process. Moreover, even if the secrecy of the convention reflected an antidemocratic bias on the framers' part, they did not offer the convention itself as a model for the new government. On the contrary, one principle they tried to build into the constitutional design was the very one to which Jefferson had appealed [in his criticism of Convention secrecy]: government not by mystique but by laws made with the informed consent of the governed. ${ }^{185}$

184. See supra Part I; infra Part VI.

185. HOFFMAN, supra note 1, at 23. A similar point can be drawn from the example of Alexander Hamilton, who embraced a substantially broader view of presidential power postratification as a member of the Washington administration than he had embraced in his careful pre-ratification separation of powers analyses. Compare supra notes 146-147 and accompanying text and notes 168-169 and accompanying text (discussing Hamilton's pre-ratification views of presidential power), with Louis Fisher, Presidential WAR POWER 27 (2004) (discussing Hamilton's views as George Washington's Secretary of State and quoting James Madison's warning that, under Hamilton's post-ratification "interpretation of executive power . . . "no citizen could any longer guess at the character of the government under which he lives"). 


\section{IMPLEMENTING THE SOLUTION: THE CONSTITUTIONALLY CONCLUSIVE NATURE OF STATUTORY OPENNESS REQUIREMENTS}

\section{A. LEGISLATIVE ACCESS DECISIONS AS THE PRACTICAL MANIFESTATION OF THE SHALLOW/POLITICALLY CHECKABLE SECRECY SOLUTION}

If the theoretical reconciliation of constitutional openness and secrecy values is the notion of shallow and politically checkable secrecy, the practical manifestation of that reconciliation is allowing the executive to operate in secret but subjecting such operation to any checks authorized through the legislative process. The statutory process itself thus would be conclusive of any Article II concerns, and any judicial enforcement provided by statute would be appropriate. ${ }^{186}$ As discussed in Part I, three major types of checks can be authorized. First, Congress can pass statutes granting the public access rights to categories of executive branch information. Second, Congress can pass statutes giving itself and its committees and subcommittees subpoena power, subject to contempt penalties, to seek information from the executive branch. ${ }^{187}$ Third, Congress can create agencies similarly empowered to demand information from the executive branch.

The statutory process is the most intuitive means to subject presidential secrecy to a public process of political questioning and consideration. As discussed earlier, the legislative process is designed to ensure relative openness and deliberation among the political branches and between those branches and the people. The legislative process thus places the parameters of openness mandates and debate about them in the sunlight, even as the policies themselves permit some secrecy.

While the legislative process constitutes a meta-level on which broad access policies are formulated, the policies so created then generate a second level of activity through which executive secrecy is overseen more directly. Thus, individuals can vindicate congressional openness policies by seeking specific pieces of information through statutes such as the FACA, ${ }^{188}$

186. This is distinct from deeming executive privilege claims political questions. Were such claims political questions, the judiciary would neither enforce statutorily based information demands nor deem them unconstitutional. Instead, the judiciary would leave each side to its own political devices to resolve such matters. Of course, there also is the theoretical possibility that Congress will invoke inherent, rather than statutory power to demand information. See, e.g., Anderson v. Dunn, 19 U.S. 204, 225-34 (1821). Congress has not, however, invoked such power in many years and non-statutory information demands are beyond this Article's scope. See supra note 47 .

187. There remains an issue as to whether Congress can require U.S. Attorneys to bring criminal suits under a criminal contempt statute. See Peterson, supra note 47, at 574-612. This issue is well beyond this Article's scope, but to the extent that such suits are brought, any executive privilege claims made in response should not prevail.

188. See supra notes $27-28$ and accompanying text. 
and congressional committees, subcommittees, and legislatively empowered agencies similarly can vindicate such policies through their investigations. This second level of activity serves two purposes. First, to the extent that it uncovers the information sought or even makes public the very search for such information, such activity furthers the process of checking executive branch secrecy in the manner prescribed by the empowering statute. The second purpose served stems from the fact that, given the President's capacity for secrecy, executive branch secrets are likely to exist in layers, with some secrets buried under other secrets. Given the layering of secrets, the capacity for a robust degree of second-level activity is important if legislative openness policies are to be vindicated. This is so because such activity is needed to illuminate information and also to strip away layers that keep some secrets deep rather than shallow. Perhaps the most famous example of such stripping of layers is the revelation of the Watergate tapes' existence. It was only through its capacity to question former presidential aide Alexander Butterfield that the Senate Select Committee on Presidential Campaign Activities discovered the tapes' existence in the first place. Once the tapes became a shallow rather than a deep secret, further legal and political maneuvering could take place in an effort to discover their content. ${ }^{189}$

Of course, this Article does not claim, nor could it claim, that all presidential secrets will remain deep or that all sought after information will remain undisclosed unless legislative access decisions are deemed constitutionally conclusive and enforceable. To the contrary, under the current system, whereby executive privilege claims often are resolved through informal political channels but also can be subject to judicial balancing, one can find any number of secrets that eventually were disclosed or made shallow. For example, the NEPDG information that Vice President Cheney has refused to disclose itself is a well-publicized, shallow secret in light of the legal and political battles over it. ${ }^{190}$ And the August 6, 2001 Presidential Daily Briefing, sought unsuccessfully by the 9/11 Joint Inquiry, became a fairly well-publicized, shallow secret through the political tussling over it. ${ }^{191}$ Additionally, the PDB eventually was disclosed, albeit to a different investigating body (the 9/11 Commission), long after it first was sought. ${ }^{192}$

Yet it remains important to deem statutory access requirements the final word in the face of executive privilege claims because constitutional principles demand it and, more concretely, because such status allows for the creation of a comprehensive and reliable framework to keep executive secrecy shallow and politically checkable. As a practical matter, the most obvious result of such status would be an increased likelihood that legislative

189. See supra notes $15-16$.

190. See, e.g., supra notes 29-31 and accompanying text.

191. See supra text accompanying note 120.

192. Id. 
access mandates will be invoked, complied with, and ultimately enforced in the face of any challenges. Indeed, as highlighted through examples cited earlier in this Article, the mere possibility of a judicial conflict can discourage access demands. ${ }^{193}$ Such discouragement is particularly significant in light of the layering of secret information. Even the tempering of information demands can impact the depth of information sought or uncovered.

Furthermore, it is theoretically significant to accord legislative access decisions constitutionally final and enforceable status. The according of such status could highlight the underlying logic outlined throughout this paper: that executive privilege clashes fundamentally are policy debates about the merits of secrecy versus openness, that constitutional structure suggests that skepticism as to pro-secrecy arguments is called for, and that constitutional structure ultimately militates toward resolving such policy debates through legislation to ensure stable political mechanisms to keep secrecy shallow and politically checkable. Among other things, such a theoretical statement might help stem a problematic shadow function played by judicial balancing tests and their underlying rationales: that of fodder for executive branch advocacy of secrecy without any serious debate about the rationales' questionable and constitutionally counterintuitive nature. ${ }^{194}$

\section{B. THE PROTECTIVE NATURE OF STATUTES'RELATIVE BREADTH AND OF THE LEGISLATNE PROCESS}

The sufficiency of the legislative process both for keeping presidential secrecy shallow and politically checkable and for safeguarding any public interest in presidential secrecy is further exemplified by considering the protections of the legislative process in combination with the relative breadth of statutes.

As for the legislative process, the importance of its open, deliberative nature for keeping secrecy shallow and politically checkable while facilitating consideration of any public interests in secrecy has already been discussed. ${ }^{195}$ It also is important to keep in mind the role of presidential participation in the process to further safeguard any public interests in secrecy. Of course, the President must sign legislation for it to become law, unless Congress and the public deem the legislation sufficiently important to override any presidential veto with a two-thirds majority vote. ${ }^{196}$ The latter occurred in the case of the 1974 FOlA Amendments that imposed de novo judicial review over executive branch determinations that information is

193. See supra text accompanying notes 51-53.

194. See supra notes $49-50$ and accompanying text.

195. See supra Part III.B.1.c.

196. U.S. CONST. art. I, $\S 7$, cl. 2. 
"properly classified." ${ }^{197}$ And while much anecdotal evidence suggests that the public generally is wary of government secrecy, ${ }^{198}$ the President is hardly at a loss for rhetorical tools in public debates over access versus secrecy. Indeed, polling suggests that when access debates are framed as matters of national security, public support for openness drops. ${ }^{199}$ Furthermore, observers note that self-serving presidential secrecy readily gets conflated with national security based secrecy. ${ }^{200}$ That the statutory process adequately protects any Article II interests is highlighted further when one considers the arduousness of the process and the fact that constitutional values militate in favor of placing any errors on the side of openness rather than secrecy in any event.

Also important is the breadth of access statutes. By their nature, statutes tend to be broad relative to their case-by-case implementation or enforcement. As noted above, the legislative process constitutes a meta-level on which policy decisions about secrecy and openness are made, while the use of any statutory authorizations constitute a second level on which particular instances of secrecy are checked actively. The meta-level decisions, or statutes, will vary in their breadth. Arguably, the broadest statutes are those that grant all congressional committees subpoena power and the power to enforce subpoenas through criminal contempt actions upon the majority vote of a congressional chamber. ${ }^{201}$ Public access statutes that specify categories of accessible information at varying levels of detail ${ }^{202}$ and statutory authorizations for specific agencies with specific missions to use and enforce subpoeanas are both typically narrower in scope. ${ }^{203}$

Statutory breadth is particularly important in bolstering protections for openness interests. While the President certainly has rhetorical tools to argue for secrecy even in broad policy debates, history and logic nonetheless suggest that Presidents, and politicians generally, will be more inclined and politically pressured to support openness as a relatively abstract value rather than as applied to particular situations. Hence, Presidents sometimes articulate broad support for policies of openness while deviating from such

197. 5 U.S.C. $\$ \S 552($ b) (1) (B), (a) (4) (B) (2000); Deyling, supra note 67, at 74-76.

198. See, e.g., Kitrosser, supra note 14, at 137-39; Noah Shactman, Secrecy Suddenly a Campaign Issue, WIRED NEws, Jan. 17, 2004, available at http://www.wired.com/news/politics/ $0,1283,61952,00 . \mathrm{html}$.

199. See The Bush Administration's Secrecy Policy: A Call to Action to Protect Democratic Values, Oct. 25, 2002, available at http://www.ombwatch.org/article/articleview/1145/1/253.

200. See, e.g., ARThur M. SChlesinger, JR., War AND the American Presidency 63 (2004); SCHLESINGER, supra note 4, at 356; Mary-Rose Papandrea, Under Attack: The Public's Right to Know and the War on Terror, 25 B.C. THIRD WORLD L.J. 35, 76-80 (2005); Wells, supra note 5, at $1197-$ 1209; Senate Panel Holds Secrecy Hearings, CNN, Mar. 25, 2005, http://www.cnn.com/ 2005/ALLPOLITICS/03/15/congress.foia.ap/index.html.

201. See supra note 47 and accompanying text.

202. See, e.g., supra note 28 and accompanying text.

203. See, e.g., supra notes 32-37 and accompanying text. 
policies in practice. ${ }^{204}$ This is similar to the arguable divide between constitutional ideals and the secrecy of the Philadelphia Convention. ${ }^{205}$ Given the significance of openness as a constitutional value and the special risks that secrecy will be used and abused on case-by-case bases, it is important that Presidents and officials be required to abide, case-by-case, with whatever access policies have been crafted on the statutory level. Of course, statutory decisions can always be amended as needed. To the extent that information "slips through" before amendment can occur, this is consistent with the notion that any access "errors" should favor openness rather than secrecy in light of constitutional values.

The protective nature of statutory breadth is exemplified by clashes over the public release of photographic evidence of the Abu Ghraib prisoner abuse. While there is good reason to believe that these photographs are covered by the FOIA and, thus, should be released, the U.S. government refused the FOIA request to release such evidence, citing exemptions from the FOIA. ${ }^{206}$ More importantly, when members of Congress were shown 1,800 Abu Ghraib slides, “[T]he overwhelming response, besides revulsion, was, in the words of Senate Armed Services Committee Chairman John Warner (R-Va.), that the pictures 'should not be made public."'207 While today's Congress is not the same Congress that passed the FOIA, Congress's response to the photos nonetheless reflects a more general phenomenon: the likelihood that officials will support abstract openness principles but be tempted to deviate from such principles on case-by-case bases. This is why breadth of statutory application is an important means to protect openness interests, just as broad free speech protections safeguard unpopular views that might not be protected were free speech doled out on case-by-case bases. The importance of broad openness protections is further exemplified by the fact that, at least for now, the FOIA's general policies seem to have prevailed over Congress's distaste for openness in the case at hand: a federal district court recently deemed disclosure of the photographs mandated under the FOIA. ${ }^{208}$

Of course, a statute's drafters can always provide for case-by-case review by the judiciary to weigh the benefits of openness against any infringement on the President's ability to perform his Article II functions. It is important, however, that such a provision itself results from a meta-policy judgment about the nature of the check that should be imposed on presidential

204. See supra Part I.

205. See supra Part III.B.2., Part III.B.3.d.

206. See ACLU v. Dep't of Def., 389 F. Supp. 2d 547, 568-79 (S.D.N.Y. 2005); Matt Welch, The Pentagon's Secret Stash: Why We'll Never See the Second Round of Abu Ghraib Photos, (Apr. 2005), available at http://www.reason.com/0504/co.mw.the.shtml.

207. Welch, supra note 206.

208. ACLU, 389 F. Supp. 2d at 568-79. 
secrecy. And, of course, any such judgment should remain subject to renewed political consideration over time.

\section{LIMITATIONS ON THE ARGUMENT}

That executive privilege does not provide a valid legal basis to invalidate statutorily authorized requests for information does not mean that there are no other such legal bases. In considering the possible validity of other legal objections to statutorily authorized requests for information, it is useful to recall the substantive nature of an executive privilege claim. Because an executive privilege claim is grounded in the President's purported need for autonomy in formulating plans and in defending national security, it is best understood as a claim that is extrinsic to the internal validity of the congressional inquiry or legislation at issue. For example, executive privilege claims against congressional committee requests are best understood as claims to the effect that, even if the committee is requesting information within the scope of Article I powers, the committee still faces an extrinsic limitation borne of the President's need for autonomy. Similarly, executive privilege claims most logically are understood as claims based on Article II and thus on the unique status of the President, rather than on privacy interests or other individual rights that might be shared by private individuals.

Given the nature of an executive privilege claim, there remains room for at least three types of objections to legislatively authorized information requests: Arguments that requested information involves matters outside of the requesting body's constitutional powers; individual-rights based arguments such as those grounded in a President's personal privacy; and statutory interpretation claims.

\section{The Scope of Congress's Legislative and Oversight Domain}

This Article's arguments for statutory finality with respect to executive privilege claims rest partly on the inter-branch and dialogic nature of most political decision-making under the Constitution. As discussed earlier, the open, deliberative, and shared nature of most political decision-making is meant to protect the public. ${ }^{209}$ This fact, combined with a broader constitutional grounding in openness, suggests that any presidential decision-making that is constrained by some level of inter-branch control is subject, among those constraints, to forced openness stemming from statutory authorization.

The connection of this Article's arguments to inter-branch checking more generally suggests the continued legitimacy of one type of argument against information requests. Specifically, it suggests the viability of arguments to the effect that such requests are internally problematic

209. See supra Part III.B.1.c. 
because they relate to a matter beyond the scope of the requesting body's powers. Thus, in the rare case that Congress or a chamber or committee thereof requests information that extends beyond its constitutional powers-say, if a House committee were to seek documents about a Supreme Court nominee unrelated to legislation and hence tied only to the senatorial "advise and consent" function-an argument might successfully be made that the requesting entity simply has no prerogative within this limited domain.

As a descriptive matter, Supreme Court review of such claims generally strikes a balance between making clear that intrinsic limits exist on the scope of Congress's legislative and oversight powers, ${ }^{210}$ while suggesting also that such scope is very broad and that deference is due Congress's judgments as to the information pertinent to its tasks. ${ }^{211}$ Thus, the drawing of some lines is deemed appropriate in those cases where Congress, or a subset thereof, seeks information about something with respect to which it has no role, as in the hypothetical House request for judicial nominee information.

It also bears noting that the logic underlying a challenge based on Congress's internal limitations militates against applying this Article's proopenness arguments to the judiciary. This is not to suggest that openness directives with respect to the judiciary are categorically unconstitutional. Indeed, there are strong arguments and some supporting doctrine suggesting that judicial or quasi-judicial proceedings alone are subject to First Amendment public access directives. ${ }^{212}$ Furthermore, limited inquiries into judicial conduct, say, for impeachment purposes, may fall within Congress's investigative domain. ${ }^{213}$ Nonetheless, because Article III is directed in part toward ensuring a substantial zone of judicial independence and because the bulk of this Article's constitutional arguments relate specifically to Articles I and II and to the political process, those arguments do not translate automatically to the realm of congressional inquiries into judicial conduct. Any arguments regarding judicial openness therefore must stand on their own.

\section{Individual Rights Based Objections}

Another viable category of argument includes individual rights claims, such as privacy claims or First Amendment claims that might be brought by

210. See, e.g., Barenblatt v. United States, 360 U.S. 109, 111-12, 132-33 (1959); Watkins v. United States, 354 U.S. 178, 187 (1957); Quinn v. United States, 349 U.S. 155, 161 (1955); Tenney v. Brandhove, 341 U.S. 367,377 (1951); McGrain v. Daugherty, 273 U.S. 135, 173-77 (1927); Kilbourn v. Thompson, 103 U.S. 168, 190, 192-95 (1880).

211. See, e.g., Barenblatt, 360 U.S. at 111-12; Watkins, 354 U.S. at 187; Tenney, 341 U.S. at 378; McGrain, 273 U.S. at $173-80$.

212. See generally, e.g., Kitrosser, supra note 14.

213. See Nixon v. United States, 506 U.S. 224 (1993) (discussing breadth of Senate's power to try impeachments of federal judges). 
the President or by other executive branch officials. While such claims are not categorically unavailing, they generally will carry less weight than would similar claims brought by private citizens given the public nature of the executive branch offices at issue. ${ }^{214}$ While a detailed discussion of the topic is beyond this Article's scope, it is useful to consider that the zones of privacy and private deliberation that the constitutional system rings around private individuals in the United States are much more robust than any such zones around government officials acting in public capacities. ${ }^{215}$ While a major premise of our constitutional system is that private individuals are autonomous beings who in many respects own and answer to themselves, another major premise of our system is that public officials acting in their public capacities are "owned by" and must answer to the people. ${ }^{216}$ Furthermore, it seems likely that any individual rights claim would overlap with a claim to the effect that the inquiry is beyond the scope of Congress's powers because it focuses predominantly on private information.

\section{Statutory Interpretation}

Finally, judicial enforcement of statutorily authorized information demands is subject to courts' statutory interpretation. While a detailed discussion of statutory interpretation is well beyond this Article's scope, three guidelines bear mention. The first cautions against judicial overreaching to construe statutes narrowly, while the second acknowledges that legislative intent to accommodate past executive privilege case law should be considered. The third emphasizes the importance of considering statutory directives as to when and how any judicial enforcement should occur.

First, to the extent that this Article questions existing executive privilege case law, it follows that the judiciary should not construe statutes narrowly to avoid constitutional questions perceived to arise under such case law. Instead, one should recognize that the weighing of the relative merits of secrecy and access conducted during the legislative process is conclusive of any questions raised by executive privilege claims. Additionally, such a change in the judiciary's approach to construing access statutes would better hold members of Congress and Presidents to the relatively broad principles articulated in statutory access decisions without enabling them to duck these principles in case-by-case fights over executive privilege, unless such case-by-

214. See, e.g., Nixon v. Adm'r of Gen. Servs., 433 U.S. 425, 455-68 (1977). It also is possible that a claim, such as a First Amendment claim, might be brought on behalf of private individuals or groups who speak with the President. See, e.g., Jay S. Bybee, Advising the President: Separation-of-Powers and the Federal Advisory Committee Act, 104 YALE L.J. 51, 120-22 (1994).

215. Cf., e.g., Nixon, 433 U.S. at 455-68; BoK, supra note 14, at 110, 246; Seth F. Kreimer, Sunlight, Secrets, and Scarlet Letters: The Tension Between Privacy and Disclosure in Constitutional Law, 140 U. PA. L. REV. 1, 67 (1991).

216. Cf., e.g., Kreimer, supra note 215 , at $6-7$. 
case fights are provided for on the meta, statutory level. These benefits are of constitutional dimension as they help to further the shallowness and political oversight of executive secrecy.

Second, complicating the matter of statutory interpretation is the fact that some access statutes may reflect assumptions that their directives are and should be challengeable in court on case-by-case bases. For example, a provision in the statute creating the $9 / 11$ Commission states that information shall be provided to the Commission pursuant to subpoenas "to the extent authorized by law. ${ }^{217}$ On the one hand, such a provision might be construed as encompassing assumptions about the law of executive privilege at the time of the statute's enactment and thus as requiring judicial balancing. On the other hand, such a provision might be construed as a catch-all provision intended to incorporate whatever law might exist at the time that a legal challenge arises. Faced with such a question, the judiciary should apply standard tools of statutory interpretation but should not employ a constitutional avoidance doctrine to err on the side of narrowness as discussed in the preceding paragraph.

Third, some statutory access directives themselves embody values of deliberativeness in overseeing executive secrecy at the secondary, case-bycase level of oversight. As noted earlier, for example, congressional committees have a statutory subpoena power and the statutory ability to enforce such power through criminal contempt actions upon the majority vote of a congressional chamber. ${ }^{218}$ The requirement of a chamber vote prior to certifying a criminal case to the U.S. Attorney ${ }^{219}$ suggests a desire to provide deliberation and open debate before forcing disclosure. While this statutory provision applies broadly to any refusals to provide information, it has special value for facilitating careful consideration of refusals grounded in executive branch autonomy values. The judiciary must ensure that any statutory procedures necessary to trigger judicial enforcement are followed. At the same time, the judiciary should not overreach to create process-based hurdles in the name of constitutional avoidance.

217. Intelligence Authorization Act for Fiscal Year 2003, Pub. L. No. 107-306, § 605(c)(1), 116 Stat. 2383, 2411 (2002). The statute also provides that "[a]ny public hearings of the Commission shall be conducted in a manner consistent with the protection of information provided to or developed for or by the Commission as required by any applicable statute, regulation, or Executive order." Id. \$606(c).

218. 2 U.S.C. $\$ \$ 192,194(2000)$.

219. Id. $\$ 194$. But see supra note 187 (noting that a separate question is raised as to whether a U.S. Attorney constitutionally can be forced by Congress to bring such a prosecution). 


\section{Reflections on the Policy Nature of the Questions at ISSUE in Executive Privilege Clashes and Judicial. Tendencies in Evaluating THOSE QUESTIONS}

This Article's constitutional arguments have force independent of how the judiciary actually handles its existing role in executive privilege disputes or of the real costs and benefits of executive secrecy. Nonetheless, some attention to these factors bolsters this Article's arguments in two respects. First, by demonstrating the very real risks and potential misuses of executive branch secrecy, such attention accentuates the fact that arguments in favor of executive privilege are mere policy judgments, and highly contestable ones at that, not static constitutional truths. Second, by demonstrating the judiciary's tendency to defer to executive privilege or to related pro-secrecy claims, particularly when national security is invoked, it suggests the wisdom of a constitutional structure grounded in the view that self-interested political forces are the best means to guard against tyrannical political secrecy.

Arguments for high-level executive branch secrecy, while surely on the mark sometimes, nonetheless are contestable policy judgments with respect to which abundant counter-arguments exist. Indeed, countless scholars, journalists, legislators, and executive branch officials have noted secrecy's judgment-clouding and security-hindering effects in relation to historic and current events. For examples of such criticism, one needs to look no further than commentary on the 2003 invasion of Iraq. It has been argued repeatedly that the reticence of the press and of Congress to ask difficult questions prior to the invasion of Iraq combined with the Bush administration's penchant for secrecy created an insular White House environment in which debate was stifled, "groupthink" ${ }^{220}$ flourished, and questionable data on weapons of mass destruction were embraced while predictions of a peaceful, post-invasion Iraq similarly went unquestioned. ${ }^{221}$

220. Barbara Ehrenreich framed the problem of groupthink and its relationship to the Iraq war well when she wrote in July of 2004: "[W] hile the capacity for groupthink is an endearing part of our legacy as social animals, it's also a common precondition for self-destruction. One thousand coalition soldiers have died because the C.I.A. was so eager to go along with the emperor's delusion that he was actually wearing clothes." Barbara Ehrenreich, Editorial, All Together Now, N.Y. Times, July 15, 2004, at A23.

221. See, e.g., Gregory P. Magarian, The First Amendment, the Public-Private Distinction, and Nongovernmental Suppression of Wartime Political Debate, 73 GEO. WASH. L. REv. 101, 118-21 (2004); Alasdair Roberts, National Security and Open Government, 9:2 GEO. PUB. POL'Y REv. 69, 75 (2004); Andrew Rosenthal, Editorial, Decoding the Senate Intelligence Committee Investigation on Iraq, N.Y. Times, July 18, 2004, $\S 4$, at 12; Ron Suskind, Without a Doubt, N.Y. TimES, Oct. 17, 2004, § 6 (Magazine), at 44; Bruce Berkowitz, Secrecy and National Security, Hoover DiG., No. 3 (2004), available at http://www.hooverdigest.org/043/berkowitz.html. Bob Drogin \& John Goetz, The Curveball Saga: How U.S. Fell Under the Spell of "Curveball," L.A. TIMES, Nov. 20, 2005, at 1, http://www.commodreams.org/headlines/05/1120-01.htm; Editorial, A Pause for Hindsight, N.Y. Times, July 16, 2004, at A20, available at http://www.nytimes.com/2004/07/16/opinion/ 
For example, three versions of a pre-invasion intelligence estimate were prepared by the administration. While all three concluded "that Saddam Hussein was a major threat ... the first, long, classified one was peppered with reservations. A declassified version that was given to Congress erased most of the doubts. The even shorter public version had no caveats at all."222 The possibly drastic consequences of such information-hoarding is evidenced by statements that "Congress would never have given President Bush a blank check for military action if it had known that there was no real evidence that Iraq was likely to provide aid to terrorists or was capable of inflicting grave damage on our country or our allies"223 and by the drop in public support for military action in Iraq as the realities of post-invasion Iraq and the weaknesses of the pre-invasion case for war surfaced. ${ }^{224}$ Intraexecutive branch secrecy also played a part in pre-invasion intelligence failures. As Bruce Berkowitz explains:

CIA analysts assessing reports from the field sometimes believed they were reading information from several sources that corroborated each other, when in fact the reports all came from a single source-and were wrong. The analysts did not know they were making a mistake because security rules designed to protect secrets-"compartmentation" and "need to know"-prevented them from knowing the identity of the source. ${ }^{225}$

Similar concerns have been raised about the negative impact of secrecy on homeland security, both prior to, and in the wake of, September 11. "Thomas H. Kean, chairman of the Sept. 11 commission and a former Republican governor of New Jersey, said the failure to prevent the 2001 attacks was rooted not in leaks of sensitive information but in the barriers to sharing information between agencies and with the public." ${ }^{226}$ Similarly, congressional investigators have observed that "CIA and National Security Agency reports regarding the terrorist threat to the United States [prior to September $11 \mathrm{th}$ ] were so highly classified that they were not even made available to FBI agents in the field who might have been able to act on

16FRI1.html; Report Slams CIA for Iraq Intelligence Failures, CNN.COM, July 9, 2004, http://www.cnn.com/2004/ALLPOLITICS/07/09/senate.intelligence/index.html.

222. Andrew Rosenthal, supra note 221, at A12; see also, e.g., Report Slams CIA for Iraq Intelligence Failures, supra note 221.

223. Editorial, A Pause for Hindsight, supra note 221; see also, e.g., Dana Milbank \& Walter Pincus, Asterisks Dot White House's Iraq Argument, WASH. POST, Nov. 12, 2005, at A1 (reporting that Congress did not have access to the same pre-war intelligence that the White House did).

224. See, e.g., Poll: Bush's Iraq Rating at Low Point, CNN.Com, Aug. 5, 2005, http://www.cnn.com/2005/POLITICS/08/05/bush.ap.ipsospoll.ap/index.html.

225. Berkowitz, supra note 221.

226. Shane, supra note 5, at 114; see also Editorial, The Dangerous Comfort of Secrecy, N.Y. TIMES, July 12, 2005, at A20. 
them." ${ }^{227}$ Concerns have been raised that the rush to hide yet more information in the wake of September 11th will prove counter-productive to the public good, keeping the public in the dark about everything from nuclear safety risks to the diminution of civil liberties. ${ }^{228}$

Similar analyses about more distant historical events abound. Writing about the Vietnam War, James C. Thompson, who served in the Kennedy and Johnson administrations during the war, posed the question: "How did men of superior ability, sound training, and high ideals-American policymakers of the $1960 \mathrm{~s}-$ create such costly and divisive policy?" ${ }^{229} \mathrm{He}$ attributed the situation partly to:

$[\mathrm{T}]$ he "closed politics" of policy-making as issues become hot: the more sensitive the issue, and the higher it rises in the bureaucracy, the more completely the experts are excluded while the harassed senior generalists take over (that is, the Secretaries, Undersecretaries, and Presidential Assistants). The frantic skimming of briefing papers in the back seats of limousines is no substitute for the presence of specialists; furthermore, in times of crisis such papers are deemed "too sensitive" even for review by the specialists. $^{23}$

Daniel Patrick Moynihan, in his extensive study of government secrecy in the United States, chronicles profound misunderstandings by the United States of the nature of the military and strategic threats posed by the Soviet Union throughout the Cold War. ${ }^{231}$ Moynihan attributes these misunderstandings and subsequent strategic missteps largely to government secrecy. ${ }^{232}$ As Richard Gid Powers explains in the introduction to Moynihan's book, Secrecy:

227. Steven Aftergood, The Bush Administration's Suffocating Secrecy, FORWARD, Mar. 28, 2003, at 9; see also, e.g., Berkowitz, supra note 221 ("Investigators examining the September 11 terrorist attacks found that intelligence organizations were often unable to share information with intelligence users and thus could not provide effective warning. In other cases, intelligence organizations could not share information with each other and thus were unable to work effectively together.").

228. See, e.g., Roberts, supra note 221, at 77-82; Trudy Lieberman, Homeland Security: What We Don't Know Can Hurt Us, Colum. Journalism Rev., Sept./Oct. 2004, at 24; Charlie Savage, In Terror War's Name, Public Loses Information, Boston GlobE, Apr. 24, 2005, at A1; The Costs of Secrecy, WASH. POST, Apr. 18, 2005, at A16; NOW with Bill Moyers (PBS television broadcast Dec. 12,2003 ) (transcript on file with Iowa Law Review).

229. James C. Thompson, Jr., How Could Vietnam Happen?, THE ATLantic, Apr. 1968, at 4753, available at http://www.echeat.com/essay.php? $\mathrm{t}=25543$.

230. Id.; see also Roberts, supra note 221, at 73-74 (discussing the Vietnam War and Thomson article). Raoul Berger also attributes much of the misguided decision-making of the Vietnam War to executive branch secrecy. BERGER, supra note 18, at 265-85.

231. See generally MOYNIHAN, supra note 2.

232. Id. 
Moynihan realized that the most pressing intelligence problems of the Cold War had really been questions for the social scientist. How dynamic was the Soviet Union? What was the strength of its economy? How stable was its social order and its ethnic structure? ... . [S] ecrecy made scientific investigation of these problems impossible, since, in order to be scientific, analysis requires that information be available to all for criticism and reevaluation. ${ }^{233}$

Moynihan also attributes the rise of McCarthyism to executive branch secrecy. Explaining Moynihan's view, Powers writes: "McCarthy would have been nothing without government secrecy. He was able to gain hearing for his fantastic charges only because he could claim that the evidence to support them was kept hidden by the executive branch."234

Moynihan's observations about Joseph McCarthy call to mind a distinct but related risk of government secrecy: that secrecy not only will be misused by well-meaning yet overzealous officials, but that it will intentionally be misused by those set on manipulating public debate toward their own ends. Indeed, McCarthy's exploitation of government secrecy calls to mind Vice President Cheney's recent attempts to perpetuate the theory of a link between Al Qaeda and Saddam Hussein through vague public allusions to evidence in the administration's possession of which others, including the 9/11 Commission, supposedly were not aware. ${ }^{235}$ Similarly, concerns long have been raised about executive branch "spinning of information" through selective declassification or leakage of otherwise classified information. ${ }^{236}$ Raul Berger invokes the likelihood of executive misuse as a counterpoint to the argument that secrecy facilitates candid discussions. Berger asks:

Can it be maintained that protection for such "candid interchange" is of greater public benefit than plenary congressional investigation which exposed the maladministration over persistent executive heel-dragging and deception? Rather, the knowledge that every such recommendation or communication will be open to scrutiny serves as an excellent deterrent to chicanery. ${ }^{237}$

These examples illustrate the extent to which policy arguments favoring executive branch secrecy often are grounded in highly questionable

233. Id. at 13; see also, e.g., id. at 181, 197-98.

234. Id. at 27.

235. See, e.g., Philip Shenon, Leaders of 9/11 Panel Answer Information Claim by Cheney, N.Y. TIMEs, July 7, 2004, at A18; Philip Shenon \& Richard W. Stevenson, Leaders of 9/11 Panel Ask Cheney for Reports that Would Support Iraq-Al Qaeda Ties, N.Y. TIMES, June 19, 2004, at A8.

236. See, e.g., Note, Keeping Secrets, supra note 12, at 910-14; Dana Priest, A Clash on Classified Documents, WASH. POST, Mar. 31, 2004, at A12.

237. BERGER, supra note 18, at 239. 
empirical assumptions. This point casts the judiciary's tendency to err on the side of deference to presidential secrecy claims in particularly harsh light.

The grounding of executive privilege claims in questionable policy judgments toward which the judiciary often defers exemplifies the wisdom of a constitutional structure reliant largely on robust inter-branch competition and resulting statutory controls to check executive branch secrecy. As I have argued elsewhere, substantive judicial intervention may be necessary as a protective floor when the political process cannot be counted on to address government secrecy, as in the context of adjudicative proceedings. ${ }^{238}$ This is not unlike the judicial role in protecting individual rights more generally - while the judiciary has been known to deemphasize individual rights in times of perceived crises, the judiciary may offer the only hope, however scant, of protection against majority tyranny in such contexts. ${ }^{239}$ Yet, it is another question entirely whether the judiciary should second-guess the substantive issues where the statutory process and a secondary, implementing body take a stand against executive secrecy. In the latter cases, constitutional structure counsels strongly in favor of letting the legislative process run its course. That this conclusion is bolstered by historical experience suggests the wisdom of the structural framework.

\section{CONCLUSION}

One of the past year's top news stories has involved revelations of an extensive, secret wire-tapping program authorized by the White House in the wake of September 11. ${ }^{240}$ The program is controversial due partly to the separation of powers issues it raises. First, despite White House protestations to the contrary, there appears to be no congressional authorization for the program. ${ }^{241}$ Second, in keeping with the lack of multi-branch involvement, the White House kept the program secret from the public and from all but a few congresspersons (who the White House ordered not to disclose the

238. Kitrosser, supra note 14 , at $130-45$.

239. See, e.g., David Cole, Judging the Next Emergency: Judicial Review and Individual Rights in Times of Crisis, 101 MICH. L. REV. 2565, 2565-68 (2003). But see generally, e.g., Oren Gross, Chaos and Rules: Should Response to Violent Crises Always Be Constitutional?, 112 YALE L.J. 1011 (2003) (arguing that extra-constitutional emergency powers should be accepted due in part to courts' poor performance in times of crisis).

240. See, e.g., Tom Daschle, Op-Ed., Power We Didn't Grant, WASH. Post, Dec. 23, 2005, at A21; Eric Lichtblau \& David E. Sanger, Administration Cites War Vote in Spying Case, N.Y. TIMES, Dec. 20, 2005, § 1, at Al; David E. Sanger, Bush Says He Ordered Domestic Spying, N.Y. TIMES, Dec. $18,2005, \S 1$, at 1 .

241. See, e.g., Daschle, supra note 240; Lichtblau \& Sanger, supra note 240; Sanger, supra note 240; Elizabeth B. Bazan \& Jennifer K Elsea, Congressional Research Serv., Presidential Authority to Conduct WarRantless Electronic Surveillance to Gather FOREIGN INTELLIGENCE INFORMATION (2006), available at http://www.fas.org/sgp/crs/ intel/m010506.pdf. 
information) until it was leaked to the press. ${ }^{242}$ Foremost among the Bush Administration's responses to the leak has been a defense of the secrecy in which it shrouded the program and criticism of those responsible for the leak. ${ }^{243}$ President Bush has argued that because of the leak, "our enemies have learned information that they should not have, and the unauthorized disclosure of this effort damages our national security and puts our citizens at risk." ${ }^{244} \mathrm{He}$ also has cautioned against public congressional hearings on the program, stating that "public hearings on programs will say to the enemy, 'Here's what they do, adjust.",245

Also in the news of late are clashes regarding the Bush Administration's unwillingness to release documents to the Senate Judiciary Committee regarding past and present executive branch work of Supreme Court nominees John Roberts, Harriet Miers, and Samuel Alito. In reference to requests for papers involving Miers, for example, President Bush told reporters: "I just can't tell you how important it is for us to guard executive privilege in order for there to be crisp decision making in the White House." $" 246$

Not only are executive privilege debates alive and well, then, but the more fundamental questions that they embody-questions as to the need and entitlement of each branch and the public for information-continue to manifest themselves in a host of issues ranging from executive privilege to informal information disputes to classification policy. An observation by Bruce Ackerman about the secret-wiretapping controversy illustrates what is at stake in these debates. Ackerman writes:

Suppose the president's legal position on the spying question were correct and that he actually had the unilateral powers his lawyers say he has. Then it would be especially important for him to exercise this authority publicly and tell us when he was creating a new spying operation. Under this scenario, the only power Americans would have left against presidential abuse is precisely the power to mobilize and insist that Congress rein the president in. By keeping his decisions a secret, the president insulates himself from the last check and balance against excess. This should have no place in a constitutional democracy. ${ }^{247}$

242. See, e.g., Lichtblau \& Sanger, supra note 240; Sanger, supra note 240; Bruce Ackerman, The Secrets They Keep, SLATE.COM, Dec. 20, 2005, http://www.slate.com/id/2132811.

243. See, e.g., Lichtblau \& Sanger, supra note 240; Sanger, supra note 240; Ackerman, supra note 242.

244. Sanger, supra note 240 .

245. Lichtblau \& Sanger, supra note 240.

246. Richard W. Stevenson, President, Citing Executive Privilege, Indicates He'll Reject Requests for Counsel's Documents, N.Y. TIMES, Oct. 5, 2005, at A21.

247. Ackerman, supra note 242. 
In other words, there can be no checks and balances-public or congressional-against a program that is implemented in secret unless the very fact of the program, including the need for secret implementation, is disclosed and publicly debated. Such public debate is not without a degree of risk, as is the possibility that the debate will lead to poor choices. But there is substantial risk as well in facilitating the deep secrecy of such programs so that even their very existence and the secrecy in which they are shrouded are immune to checks. Constitutional text, structure, and history suggest that government should err on the side of openness and checking. More precisely, text, structure, and history suggest that while secrecy is not categorically illegitimate, it must remain a shallow and politically controllable tool of the people, subject to the checks and balances that characterize the federal political system as a whole and that are meant to serve as bulwarks against tyranny. 


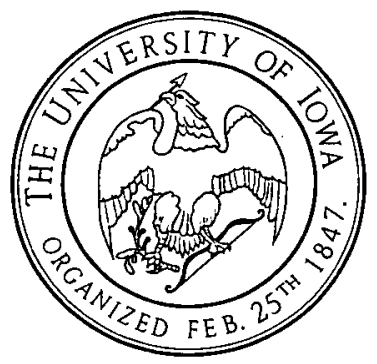

